\title{
Genes responsible for proliferation, differentiation, and junction adhesion are significantly up-regulated in human ovarian granulosa cells during a long-term primary in vitro culture
}

\author{
Wiesława Kranc ${ }^{1}$ - Maciej Brązert' ${ }^{2}$. Joanna Budna ${ }^{3}$. Piotr Celichowski ${ }^{3}$ - Artur Bryja ${ }^{1}$ - Mariusz J. Nawrocki ${ }^{1}$. \\ Katarzyna Ożegowska ${ }^{2} \cdot$ Maurycy Jankowski ${ }^{1}$ - Błażej Chermuła ${ }^{2} \cdot$ Marta Dyszkiewicz-Konwińska ${ }^{1,4} \cdot$ Michal Jeseta $^{5}$. \\ Leszek Pawelczyk ${ }^{2}$ - Andrzej Bręborowicz ${ }^{6}$. Dominik Rachoń ${ }^{7} \cdot$ Małgorzata Bruska $^{1} \cdot$ Michał Nowicki $^{3}$. \\ Maciej Zabel ${ }^{8,9} \cdot$ Bartosz Kempisty $^{1,3,5}$
}

Accepted: 20 October 2018 / Published online: 31 October 2018

(c) The Author(s) 2018

\begin{abstract}
The human ovarian granulosa cells (GCs) surround the oocyte and form the proper architecture of the ovarian follicle. The ability of GCs to proliferate and differentiate in the conditions of in vitro culture has been proven. However, there is still a large field for extensive investigation of molecular basics, as well as marker genes, responsible for these processes. This study aimed to find the new marker genes, encoding proteins that regulate human GCs in vitro capability for proliferation and differentiation during long-term primary culture. The human follicular GCs were collected from hyper-stimulated ovarian follicles during IVF procedures and transferred to a long-term in vitro culture. The culture lasted for 30 days, with RNA samples isolated at days $1,7,15,30$. Transcriptomic analysis was then performed with the use of Affymetrix microarray. Obtained results were then subjected to bioinformatical evaluation and sorting. After subjecting the datasets to KEGG analysis, three differentially expressed ontology groups "cell differentiation" (GO:0030154), "cell proliferation" (GO:0008283) and "cell-cell junction organization" (GO:0045216) were chosen for further investigation. All three of those ontology groups are involved in human GCs' in vitro lifespan, proliferation potential, and survival capability. Changes in expression of genes of interest belonging to the chosen GOs were validated with the use of RT-qPCR. In this manuscript, we suggest that $V C L$, PARVA, FZD2, NCS1, and COL5A1 may be recognized as new markers of GC in vitro differentiation, while KAT2B may be a new marker of their proliferation. Additionally, SKI, GLI2, FERMT2, and $C D H 2$ could also be involved in GC in vitro proliferation and differentiation processes. We demonstrated that, in long-term in vitro culture, GCs exhibit markers that suggest their ability to differentiate into different cells types. Therefore, the higher expression profile of these genes may also be associated with the induction of cellular differentiation processes that take place beyond the long-term primary in vitro culture.
\end{abstract}

Keywords Granulosa cells $\cdot$ Proliferation $\cdot$ Differentiation $\cdot$ Stem cells $\cdot$ Microarrays

\section{Introduction}

Folliculogenesis and oogenesis start in the early embryo and continue until the very end of the reproductive period. During fetal life, the primordial follicles are formed. A primordial follicle contains the oocyte (arrested in the pro-

Electronic supplementary material The online version of this article (https://doi.org/10.1007/s00418-018-1750-1) contains supplementary material, which is available to authorized users.

Bartosz Kempisty

bkempisty@ump.edu.pl

Extended author information available on the last page of the article phase of the first meiotic division), surrounded one layer of flat follicular cells and basal lamina. Successive stages of oogenesis and folliculogenesis occur after birth. During folliculogenesis, secondary and tertiary follicles are formed. From puberty to menopause, every month, one follicle usually matures. Before ovulation, four types of granulosa cells 
(GCs) of common origin: theca interna, mural granulosa cells, cumulus oophorous, and corona radiata, are located inside the mature (preovulatory) follicle (Chachuła et al. 2016; Rybska et al. 2018). While their structural function in follicular architecture is prominent, recent studies also suggested that ovarian GCs may display a more important role in the follicular development of the oocytes (Gao et al. 2014; Kranc et al. 2016, 2017a). Under physiological conditions, GCs have an inhibitory effect on the meiosis process occurring in the oocyte, affecting oocytes through the follicular fluid (Tsafriri and Channing 1975; Kranc et al. 2018). It was shown that early denuded oocytes do not finish their nuclear and/or cytoplasmic maturation, which needs to be completed before fertilization (Tanghe et al. 2002; Kranc et al. 2017c). Experiments on porcine GCs indicated that these cells manifest a significant expression of gap junction connection (GJC) genes and proteins (Antosik et al. 2010; Kempisty et al. 2014b). That data implied that not only CCs but also GCs may mediate the somatic cell-oocyte "dialogue" and permanent transport of small metabolites, necessary for the support of proper growth and development of the gamete (Dumesic et al. 2015; Russell et al. 2016; Budna et al. 2017). Hence, it is suggested that human GCs are more than remnant material, which is often disposed of during in vitro procedures in animals and humans, and could instead serve in potential research and clinical applications. Therefore, we have used microarrays to search for the new marker genes involved in junction connections and cellular adherence in human ovarian GCs during their longterm in vitro culture. These experiments may bring a new light into the function of human GCs as the cells involved in important somatic cell-oocyte connections, as well as mediators in metabolic pathways crucial for the growth of both oocytes and the somatic cells themselves.

Experiments performed on porcine GCs indicated that these cells are characterized by an increased ability for proliferation during in vitro culture. It was also well-recognized that GCs display significant expression of luteinizing hormone (LH), follicle-stimulating hormone (FSH) and P450 aromatase, which belong to markers of GC luteal differentiation, in the first $48 / 72 \mathrm{~h}$ of short-term in vitro culture (Kempisty et al. 2015). The in vitro proliferation of porcine GCs was substantially accompanied by changes in the transcriptomic profile (unpublished data). Therefore, it is suggested that GCs undergo significant biochemical modifications in long-term primary culture, which may also be a sign of cellular differentiation. Kossowska-Tomaszczuk et al. have recently shown that human GCs may be induced to differentiate into chondroblasts, osteoblasts, and neuroblasts, if placed in a long-term in vitro culture based on specifically supplemented differentiating medium (Kossowska-Tomaszczuk et al. 2009). These experiments indicated a huge stemlike specificity and plasticity of human GCs in primary culture. These results label GCs as potential candidates for future use as allografts in regenerative and reconstructive medicine (Jankowski et al. 2018; Kranc et al. 2018). In this study, we aim to recognize the expression patterns of genes involved in their in vitro proliferation and differentiation. These genes could potentially be used as markers of in vitro developmental capability of human GCs.

\section{Materials and methods}

\section{Patients and collection of granulosa cells}

The GCs were derived from patients undergoing in vitro fertilization (IVF), who had given their informed, written consent to participate in the research and be included in this protocol. The study group consisted of 8 patients, aged 18-40 years, with diagnosed infertility, referred to the Division of Infertility and Reproductive Endocrinology, Poznan University of Medical Sciences, Poland. The procedure was based on controlled ovarian hyperstimulation protocol, adjusted to the patient's initial infertility workup and ovarian response. Stimulation was performed using recombinant FSH (Gonal-F, Merck Serono) and highly purified hMG-HP (Menopur, Ferring). Cetrorelix acetate injections (Cetrotide, Merck Serono) were administered in an adequate dose, to suppress pituitary function. Ovulation triggering was based on a subcutaneous injection of $6500 \mathrm{U}$ of hCG (Ovitrelle, Merck-Serono). Follicular fluid, containing GCs, was collected during transvaginal, ultrasound-guided oocyte pickup, $36 \mathrm{~h}$ after human chorionic gonadotropin administration. The content of follicles that were over $16 \mathrm{~mm}$ in diameter was passed immediately to an embryologist, who isolated the oocyte and pooled the fluids containing GCs together from each ovary. The fresh follicular fluid was centrifuged for $10 \mathrm{~min}$ at $200 \mathrm{~g}$, to separate and collect GCs. Patients with polycystic ovary syndrome (PCOS), endometriosis, and diminished ovarian reserve (serum anti-müllerian hormone less than $0.7 \mathrm{ng} / \mathrm{mL}$, and/or day 2-3 FSH serum level higher than $15 \mathrm{mU} / \mathrm{mL}$, and/or antral follicle count less than 9) were excluded from the study. The research has been approved, with resolution 558/17, by Poznan University of Medical Sciences Bioethical Committee.

\section{Primary cell culture}

The collected cells were washed twice by centrifugation $(200 \times g, 10 \mathrm{~min}$ at RT), using culture medium. Medium consisted of Dulbecco's Modified Eagle's Medium (DMEM, Sigma-Aldrich, USA), 2\% fetal bovine serum FBS (FBS; Sigma-Aldrich Co., St. Louis, MO, USA), $200 \mathrm{mM} \mathrm{L-glu-}$ tamine, $10 \mathrm{mg} / \mathrm{ml}$ gentamicin 10,000 units $/ \mathrm{ml}$ penicillin, and $10,000 \mu \mathrm{g} / \mathrm{ml}$ streptomycin (all Invitrogen, Carlsbad, 
CA, USA). Cells were cultivated at $37{ }^{\circ} \mathrm{C}$ under aerobic conditions $\left(5 \% \mathrm{CO}_{2}\right)$. Once adherent cells were more than $90 \%$ confluent, they were detached by applying $0.05 \%$ trypsin-EDTA solution (Invitrogen, USA) for 1-2 min and counted using a "Neubauer improved" chamber counting (ISO LAB Laborgerate GmbH, DIN EN ISO CERTIFIED 9001). GCs were then cultivated for 30 days. The medium was changed twice a week. Finally, total RNA was isolated from the cells after 1, 7, 15 and 30 days of IVC.

\section{Immunofluorescence analysis of LHR and FSHR expression}

To confirm their identity, GCs were transferred to $35 \mathrm{~mm}$ bottom glass dishes (MatTek Corporation, Ashland, USA) according to the normal procedure described above. After 1,7 and 30 days of culture, the cells were fixed in $4 \%$ paraformaldehyde (PFA) solution for $10 \mathrm{~min}$ at room temperature (RT). To block non-specific binding, samples were incubated in 3\% BSA in PBS for $30 \mathrm{~min}$ at RT. Then, they were incubated for $1 \mathrm{~h}$ at RT with the rabbit monoclonal anti-luteinizing hormone receptor antibody (anti-LHR, ab103874; Abcam, Cambridge, UK) or goat polyclonal antifollicle-stimulating hormone receptor antibody (anti-FSHR, sc-26341; Abcam, Cambridge, UK), diluted 1:500 in PBS. Afterwards, the samples were rinsed with PBS and incubated for another $1 \mathrm{~h}$ in RT with fluorescein isothiocyanate (FITC)-conjugated donkey anti-goat IgG (MFP488, MoBiTech GmbH, Göttingen, Germany) and/or goat anti-rabbit IgG (ab6717, Abcam, Cambridge, UK), respectively, diluted 1:500 in PBS. Finally, the samples were stained with $0.1 \mu \mathrm{g} /$ ml 4,6-diamino-2-phenylindole (DAPI; Santa Cruz Biotechnology, Santa Cruz, CA, USA) and examined under confocal Fluoview 10i microscope (Olympus, Tokyo, Japan). FITC was excited with an argon laser at $488 \mathrm{~nm}$, with emissions imaged through a $505-530 \mathrm{~nm}$ filter. All the resulting images were analyzed using Imagis 7.2 Software (BitPlane, Zurich, Switzerland).

\section{Total RNA isolation}

The modified Chomczyński-Sacchi method was used to isolate the total RNA (Chomczynski and Sacchi 1987). The GCs were suspended in $1 \mathrm{ml}$ of guanidine thiocyanate and phenol mixture in monophase solution (TRI Reagent ${ }^{\circledR}$, Sigma-Aldrich, USA, St. Luis). After further addition of chloroform, the sample was centrifuged until three visible phases were obtained. RNA was located in the upper, aqueous phase. The resulting RNA was intact, with little or no contaminating DNA and protein. The last step was the stripping of RNA with 2-propanol (Sigma-Aldrich, USA, St. Luis, catalogue number I9516), added in an amount appropriate for $1 \mathrm{~mL}$ of TRI reagent used, followed by washing with $75 \%$ ethanol. RNA prepared in that way was used for further analysis.

\section{Microarray expression analysis and statistics}

To investigate the transcriptomic changes, whole gene expression analysis was performed with the use of Affymetrix ${ }^{\circledR}$ Human Genome U219 Array (Affymetrix, Santa Clara, CA, USA). Total RNA (100 ng) from each pooled sample was subjected to two rounds of sense cDNA amplification (Ambion ${ }^{\circledR}$ WT Expression Kit; Ambion Inc., Foster City, CA, USA). The obtained cDNA was used for biotin labelling and fragmentation by Affymetrix GeneChip ${ }^{\circledR}$ WT Terminal Labeling and Hybridization. Biotin-labelled fragments of cDNA $(5.5 \mu \mathrm{g})$ were hybridized to the Affymetrix ${ }^{\circledR}$ Human Genome U219 Array $\left(48^{\circ} \mathrm{C} / 20\right.$ h). Microarrays were then washed and stained, according to the technical protocol, using the Affymetrix GeneAtlas Fluidics Station. The array strips were scanned employing the Imaging Station of the GeneAtlas System. Preliminary analysis of the scanned chips was performed using Affymetrix GeneAtlasTM Operating Software (all Affymetrix, Santa Clara, CA, USA). The quality of gene expression data was confirmed according to the control criteria provided by the software. The obtained CEL files were imported into downstream data analysis software. All the presented analyses and graphs were plotted using Bioconductor and R programming languages. Each CEL file was merged with a description file. Subsequently, the Robust Multiarray Averaging (RMA) algorithm was used to correct background, as well as normalize and summarize the results. Statistical significance of the analyzed genes was determined using moderated $t$ statistics from the empirical Bayes method. The obtained $p$ value was corrected for multiple comparisons using Benjamini and Hochberg's false discovery rate. The selection of significantly altered genes was based on a $p$ value beneath 0.05 and expression change higher than twofold. The list of differentially expressed genes (separated into up- and downregulated groups) was uploaded to the DAVID (Database for Annotation, Visualization, and Integrated Discovery) software (Huang et al. 2007). Selected genes were input into the STRING (Search Tool for the Retrieval of Interacting Genes/Proteins) software, to analyze their predicted interactions. STRING is a huge database containing information on protein/gene interactions, including experimental data, computational prediction methods, and public text collections (von Mering et al. 2004). The predictions were based on text mining, co-expression, and experimentally observed interactions.

The representation of differently expressed genes in "adherens junction" and "tight junction" KEGG pathways was marked using Pathview Bioconductor package (Luo and Brouwer 2013). 
To further investigate the chosen genes belonging to "cell differentiation" (GO:0030154), "cell proliferation" (GO:0008283) and "cell-cell junction organization" (GO:0045216) GO terms, their mutual relations were investigated using the GOplot package (Walter et al. 2015). The GOplot package also allowed for calculation of the $Z$ score (the number of up-regulated genes minus the number of down-regulated genes divided by the square root of the count). The $Z$ score analysis allowed for the comparison of the enrichment of selected GO BP terms.

\section{Real-time q-PCR analysis}

The RT-qPCR was used to confirm the results obtained through expression microarrays. Three genes showing the highest, lowest, and intermediate level of expression were selected from each heatmap. Changes in the level of expression of those genes were then examined. Three biological samples of each gene were used for the analysis. Each biological test was performed in three technical replicates. Reverse transcription was based on the protocols and reagents of SABiosciences (RT ${ }^{2}$ First Stand Kit -330401), using a Veritimer 96 well Thermal Cycler. $1 \mu \mathrm{g}$ of each gene's RNA transcript was used for reverse transcription. Real-time PCR was performed using the 7900HT Fast Real-Time PCR System (Applied Biosystems), $\mathrm{RT}^{2} \mathrm{SYBR}^{\circledR}$ Green ROX ${ }^{\mathrm{TM}}$ qPCR Master Mix (Qiagen Sciences, Maryland, USA), and sequence-specific primers (Table 1). Glyceraldehyde3-phosphate dehydrogenase (GADPH), $\beta$-actin (ACTB), and hypoxanthine phosphoribosyltransferase 1 (HRPT1) were used as reference genes. Gene expression was analyzed using the relative quantification (RQ) method. The q-PCR starters were designed using Primer3Plus software (http://primer3plus.com/cgi-bin/dev/primer3plus.cgi). The sequences of the respective genes were taken from the Ensembl database (http://www.ensembl.org/index.html), from which only the sequence of exons was exported, as the target sequence of the designed starter was spread across
Table 1 Primers.

Oligonucleotide sequences of primers used for RT-qPCR analysis

\begin{tabular}{|c|c|c|c|}
\hline Gene & Gene accession numer & Primer sequence $\left(5^{\prime}-3^{\prime}\right)$ & $\begin{array}{l}\text { Product } \\
\text { size (bp) }\end{array}$ \\
\hline CSRP3 & NM_003476 & $\begin{array}{l}\text { ACAGGCAGACTTGACCTTGAC TCA } \\
\text { CAGGCTCCACATTTTGC }\end{array}$ & 77 \\
\hline FZD2 & NM_001466 & $\begin{array}{l}\text { TTCCACCTTCTTCACTGTCACC } \\
\text { AGCAGCCCGACAGAAAAATG }\end{array}$ & 89 \\
\hline GADD45B & NM_015675 & $\begin{array}{l}\text { TGATGAATGTGGACCCAGACAG } \\
\text { TGAGCGTGAAGTGGATTTGC }\end{array}$ & 96 \\
\hline SPAG16 & NM_024532 & $\begin{array}{l}\text { GTTGGGCAGATTTCTGGACTTC } \\
\text { TGGCTTCACGAAGACCTTTC }\end{array}$ & 145 \\
\hline OSR1 & NM_145260 & $\begin{array}{l}\text { TTCAGCTAAAGCCCCAGAGAC } \\
\text { TGGCTTCTCAATCCGGATCTTG }\end{array}$ & 70 \\
\hline ITGA6 & NM_001079818 & $\begin{array}{l}\text { TTTATCGGTCTCGGGAGTTGC } \\
\text { ATAGCTTGCTCGCCAACAAC }\end{array}$ & 72 \\
\hline EDN2 & NM_001956 & $\begin{array}{l}\text { TGTTCCAGACTGGCAAGACAG } \\
\text { TGACTGTGGAAATGTCCCTCAG }\end{array}$ & 72 \\
\hline TESC & NM_017899 & $\begin{array}{l}\text { TCAGCCTACCATTCGCAAGG } \\
\text { TTGTCGAAGAAGGCACGAAC }\end{array}$ & 93 \\
\hline TGFBR1 & NM_004612 & $\begin{array}{l}\text { AGAGCTGTGAAGCCTTGAGAG } \\
\text { TTCCTGTTGACTGAGTTGCG }\end{array}$ & 122 \\
\hline CDC6 & NM_001254 & $\begin{array}{l}\text { TCAATTCTGTGCCCGCAAAG } \\
\text { TAGCTCTCCTGCAAACATCCAG }\end{array}$ & 74 \\
\hline LIMS1 & NM_001193482 & $\begin{array}{l}\text { GTGGCATGTGGAGCATTTTG } \\
\text { AACACGATTGCAGTGGAAGC }\end{array}$ & 142 \\
\hline PKP2 & NM_004572 & $\begin{array}{l}\text { ATGCTAAAGGCTGGCACAAC } \\
\text { ACCTTTCTTCCACGGACTTCTG }\end{array}$ & 91 \\
\hline CADM1 & XM_017017461 & $\begin{array}{l}\text { GCTAAAAGGCAAATCGGAGGTG } \\
\text { TTGTGCACCTTCAGCATCAG }\end{array}$ & 74 \\
\hline GAPDH & NM_002046 & $\begin{array}{l}\text { TCAGCCGCATCTTCTTTTGC } \\
\text { ACGACCAAATCCGTTGACTC }\end{array}$ & 90 \\
\hline ACTB & NM_001101 & $\begin{array}{l}\text { AAAGACCTGTACGCCAACAC CTCAGG } \\
\text { AGGAGCAATGATCTTG }\end{array}$ & 132 \\
\hline HPRT & NM_000194 & $\begin{array}{l}\text { TGGCGTCGTGATTAGTGATG } \\
\text { ACATCTCGAGCAAGACGTTC }\end{array}$ & 141 \\
\hline
\end{tabular}


the border of two adjacent exons. This approach was used as a precaution against the possibility of a non-specific DNA template-based product (DNAse contained in the reverse transcription kit that was used as the other precaution). The primer attachment temperature was the geometric mean of all used primers.

\section{Results}

\section{The general outcomes of the microarray analysis}

From the whole transcriptome, consisting of 2579 different genes, 626 were up-regulated and 831 were down-regulated after 7 days of culture, 829 were up-regulated and 936 were down-regulated after 15 days of culture, while 926 were upregulated and 1126 were down-regulated after 30 days of culture. Differences were usually only observed between day 1 and the further periods of culture.

The DAVID software analysis showed that the differentially expressed genes belong to 582 Gene Ontology groups and 45 KEGG pathways. In this paper, we focused on genes which belong to the "adherens junction" and "tight junction" pathways from Kyoto Encyclopedia of Genes and Genomes (KEGG), as well as to "cell differentiation" (GO:0030154), "cell proliferation" (GO:0008283) and "cell-cell junction organization" (GO:0045216) gene ontology groups. Upand down-regulated gene sets were subjected to the DAVID search separately. Only the gene sets where adj. $p$ value was lower than 0.05 were selected. Subsequently, the expression levels of genes belonging to "adherence junction" and "tight junction" KEGG pathways were marked on the graphs, using the "path view" - a toolset for pathway based data integration and visualization (Luo and Brouwer 2013) (Figs. 1,2). The fold changes and adj. $p$ values of those genes are shown in Tables 2 and 3.

Selected GO BP terms were subjected to hierarchical clusterization procedure and presented as heatmaps (Fig. 3). Fold changes in expression of all analyzed genes, their Entrez IDs, and adjusted $p$ values were shown in Supplementary Table 1.

To further investigate the changes within the chosen GO BP terms, the enrichment levels of each selected GO BP term were measured. The enrichment levels were expressed as z-scores and presented as a circular visualization (Fig. 4).

\section{Further analysis of microarray}

In the Gene Ontology database, genes that formed one particular GO group can also belong to other different GO term categories. For this reason, the gene intersections between the selected GO BP terms were explored. The exact amount of up-regulated and down-regulated genes that are shared within GO BP terms were presented as a Venn diagram (Fig. 5). Subsequently, to focus on selected genes, the mutual relation between GO BP terms was investigated. The results are presented as a circle plot (Fig. 6) as well as heatmap (Fig. 7).

Of all the genes representing the above ontological groups, the following were chosen: VCL, FERMT2, LIMS1, ILK, PINCH1, TGFB, CDH2, PARVA, FZD2, NCS1, SKI, GLI2, KAT2B, COL8A1, CSRP3, GADD45B, SPAG16, OSR1, ITGA6, EDN2, TESC, TGFBR1, CDC6, PKP2, CADM1, CAV1, PALLD, NXN, NEXN, CTGF, TOP2A, GSTA1, KRT19, ANLN, SFRP4, CDH13, PERP, NF2, RAC1, ARL2, DLG1, GREM1, CTTN, PVR, PARD6G, EREG, TNFSF11, STAR, AREG, IL3. The STRING figure presents the analysis of interactions between the selected genes (considered the most important in the processes related to GC differentiation and proliferation, used for validation of results, and exhibiting the highest and lowest expression) (Fig. 8).

\section{Real-time qPCR validation}

RT-qPCR reactions were used to validate the microarray results. Examples of genes exhibiting each expression pattern that showed the biggest (CSRP3, FZD2, GADD45B, EDN2, LIMS1), smallest (SPAG16, TESC, TGFBR1, PKP2), and the most intermediate (OSR1, ITGA6, CDC6, CADM1) changes in expression, were chosen. Overall, the changes in expression of the analyzed gene transcripts were confirmed in every example. However, while the qualitative validation was a success, the quantitative results were not always corresponding between RT-qPCR and microarrays. Obtained values were presented in a form of a bar graph (Fig. 9).

\section{Changes in morphology of granulosa cells}

A substantial change in GCs' morphology was observed during the long-term primary in vitro culture. Multiple cultures were performed at the same time, with the majority of them presenting comparable morphology changes which, in our opinion, deemed the GCs viable for our research. The alterations in morphology were observable, as the cells changed their morphology from epithelial-like to fibroblast-like during the time of the culture (Fig. 10).

\section{Immunofluorescence analysis of LHR and FSHR expression}

Immunofluorescence analysis of LHR and FSHR localization and distribution in cultured GCs showed that expression of receptors decreased during long-term in vitro culture (Suppl. Figure 1). It was clearly observed at 1 day and then gradually diminished, being slightly visible on the 7th day 
ADHERENS JUNCTION
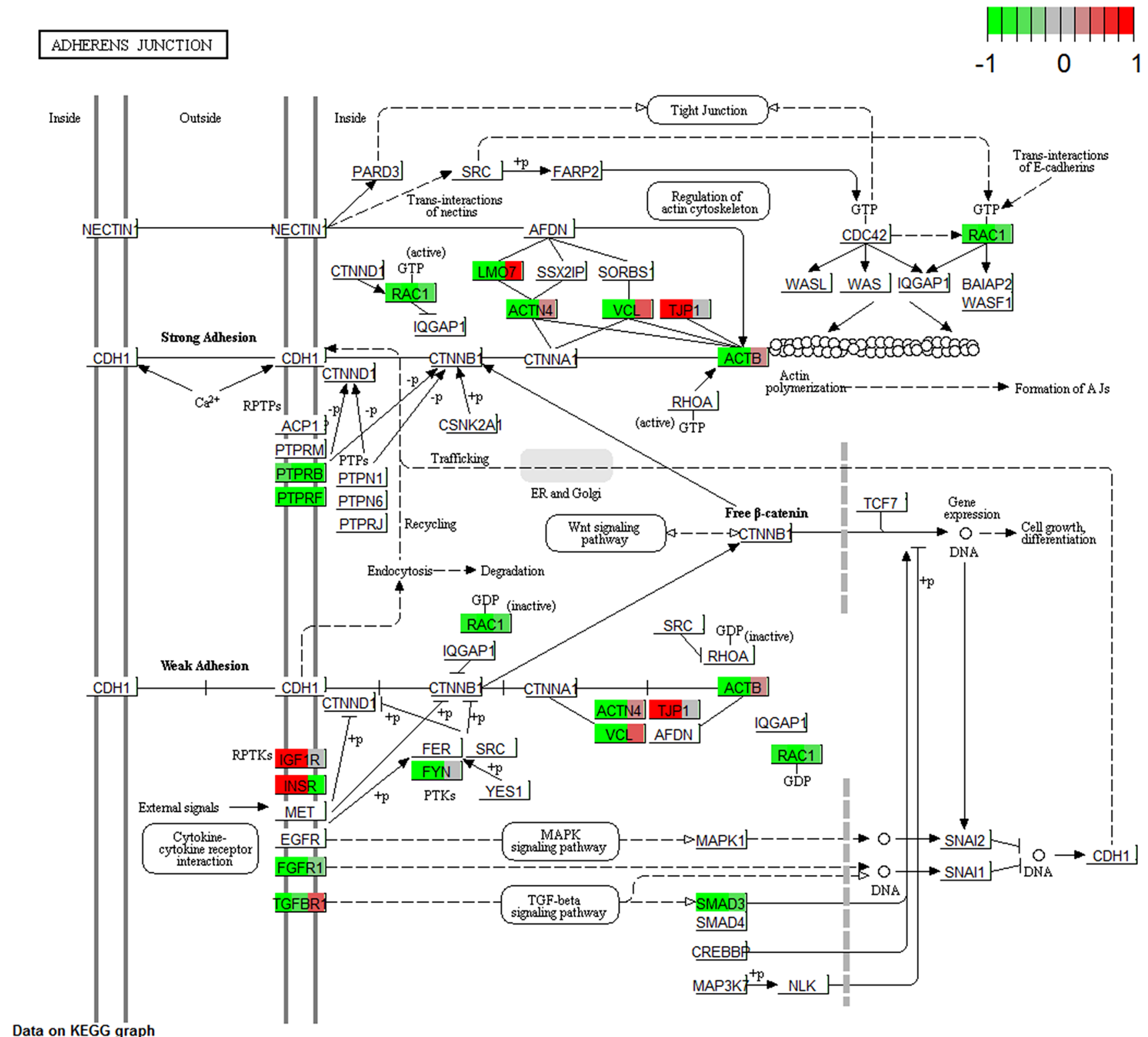

Rendered by Pathview

Fig. 1 The "adherence junction" KEGG pathway with marked expression levels of differently expressed genes. Arbitrary signal intensity, acquired from microarray analysis, is represented by col-

and totally negative on day 30 . This proves that GCs are initially present in the culture but change their character and gain new properties during long-term cultivation.

\section{Discussion}

GCs play an important role in the formation of the ovarian follicle. It is known that, in addition to the hormonal secretory function, they also play an important role in communication with oocytes. It is possible thanks to proteins called ours (green, higher; red, lower expression). The boxes with names of genes were separated into three parts containing the representation of gene expression from the 7th, 15th and 30th day of culture

connexins, forming gap-junctions connections (GJCs), enabling the transfer of nutrients and stimulating agents between GCs and the oocyte (Kempisty et al. 2014a). This has been demonstrated by many examples on various animal models, including pig (Anderson et al. 2009; Kranc et al. 2017b; Truman et al. 2017).

In recent years, an interest has grown in exploring the differentiation potential of various tissue types, especially that of present populations of cells with stem-like features. These processes involve the differentiation of less specialized cells into more counterparts, with their subsequent, progressive 


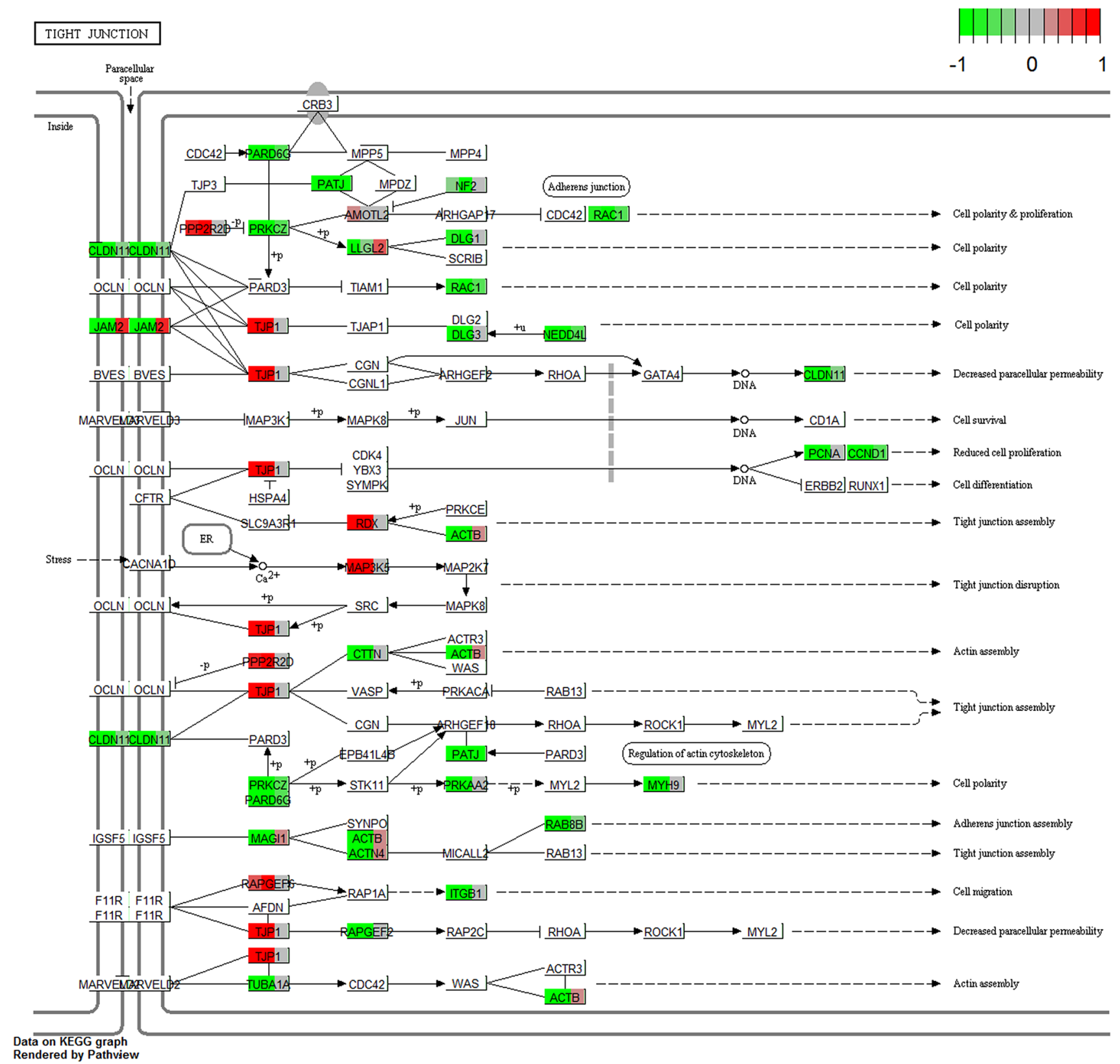

Fig. 2 The "tight junction" KEGG pathway with marked expression levels of differently expressed genes. Arbitrary signal intensity, acquired from microarray analysis, is represented by colours (green,

lineage commitment (Avior et al. 2016). It was suggested that GCs exhibit stem-like properties during long-term IVC. In a pioneering research, Kossowska-Tomaszczuk et al. suggested that GCs may differentiate into osteoblasts, chondrocytes, and neuroblasts under the influence of appropriate differentiating factors (Kossowska-Tomaszczuk et al. 2009). Other studies have shown that GCs can also differentiate toward muscle cells (Brevini et al. 2014).

The aim of this article was to present new, poorly understood properties of GCs. Our research has revealed gene higher; red, lower expression). The boxes with names of genes were separated into three parts containing the representation of gene expression from the 7th, 15th and 30th day of culture

ontology groups characterizing proliferative and differentiative potential of the granulosa. However, no supplementation with differentiating factors was used. Because of that, we cannot indicate the specific direction of differentiation. Hence, we have only selected and highlighted the genes that were possibly related to the GC differentiation process, being aware of their described potential to differentiate towards other cell types (Kossowska-Tomaszczuk et al. 2010; Brevini et al. 2014) (main functions of selected genes have been summarized in Supplementary Table 2). 
Table 2 Differentially expressed genes belonging to "adherence junction"

\begin{tabular}{|c|c|c|c|c|c|c|c|}
\hline Official gene symbol & foldD7_D1 & foldD15_D1 & foldD30_D1 & adj. $p$. value D1_D7 & $\begin{array}{l}\text { adj. } p . \text { value } \mathrm{D} 1{ }_{-} \\
\text {D15 }\end{array}$ & $\begin{array}{l}\text { adj. } p . \text { value } \mathrm{D} 11_{-} \\
\text {D30 }\end{array}$ & Entrez Gene \\
\hline TJP1 & 0.3867947 & 0.3770188 & 0.4099497 & 0.0130768 & 0.0106094 & 0.0124798 & 7082 \\
\hline INSR & 0.3873414 & 0.8061633 & 0.5346824 & 0.0490067 & 0.6204884 & 0.124498 & 3643 \\
\hline IGF1R & 0.4564233 & 0.4255477 & 0.3166935 & 0.0747752 & 0.052006 & 0.0193157 & 3480 \\
\hline PTPRB & 1.3851168 & 10.794593 & 2.9568251 & 0.7074275 & 0.0155286 & 0.1342982 & 5787 \\
\hline $\mathrm{RAC1}$ & 1.5261235 & 2.052283 & 2.3791522 & 0.1905251 & 0.0425477 & 0.0220353 & 5879 \\
\hline FGFR1 & 1.7839941 & 2.1815486 & 3.4704025 & 0.1721854 & 0.0725808 & 0.0163142 & 2260 \\
\hline SMAD3 & 1.977835 & 2.6686384 & 2.3233728 & 0.0746144 & 0.0227799 & 0.0327692 & 4088 \\
\hline ACTB & 1.9832451 & 1.6575768 & 2.1164596 & 0.0178824 & 0.0395711 & 0.0106134 & 60 \\
\hline TGFBR1 & 2.1889956 & 1.5854182 & 1.4680103 & 0.026412 & 0.1065456 & 0.1556766 & 7046 \\
\hline ACTN4 & 2.5842058 & 2.3022849 & 2.6961029 & 0.0016345 & 0.0021662 & 0.0010491 & 81 \\
\hline PTPRF & 2.7028776 & 4.7708528 & 4.2652909 & 0.0310595 & 0.0069323 & 0.0076285 & 5792 \\
\hline FYN & 2.7655141 & 2.90417 & 2.6326987 & 0.0257378 & 0.0200935 & 0.0242376 & 2534 \\
\hline ACTN1 & 3.6591712 & 3.1534043 & 3.6697117 & 0.0008244 & 0.0010905 & 0.0006175 & 87 \\
\hline VCL & 4.8645726 & 3.3807533 & 5.783599 & 0.020792 & 0.0407899 & 0.0119742 & 7414 \\
\hline LMO7 & 28.286136 & 14.459734 & 24.18382 & 0.0015722 & 0.002502 & 0.0012393 & 4008 \\
\hline
\end{tabular}

Fold changes, adjusted $p$ values and Entrez Gene ID of differentially expressed genes belonging to the "adherence junction" KEGG pathway. Symbols and names of the selected genes are also shown

The presented research combines the analysis of changes that occur during long-term in vitro culture of human GCs. These include morphology, expression of GC characteristic receptors (LHR and FSHR), as well as expression of genes characteristic for cell proliferation and differentiation.

Our first observation clearly demonstrated significant alterations in the morphology of cultured GCs, staying in accordance with the results of several previous studies. It was well-documented that, at the beginning of IVC, the GCs usually present a epithelial-like structure. Then, after several weeks of culture, accompanied by reaching full confluency, the cells adopt fibroblast-like morphology (Quinn et al. 2006; Oki et al. 2012).

Another change was related to the decreasing expression of LH and FSH receptors on the surfaces of analyzed cells, during the time of culture. The major difference was seen after the seventh day of culture when LHR and FSHR expression was almost completely lost and confirmed on day 30 when the result was totally negative. A similar observation was made by the research group of Kossowka-Tomaszczuk. However, their GCs lost FSHR expression after 17 days of culture (Kossowska-Tomaszczuk et al. 2010). Interestingly, our GCs kept proliferating until the 30th day of IVC. This fact is surprising, keeping in mind that under physiological conditions, after about 10 days post-ovulation, GCs turn into the corpus luteum and then into an inactive corpus albicans, ending their proliferation (Niswender et al. 2000; Stocco et al. 2007). Taking these observations together, we can assume that GCs acquire new properties under longterm in vitro conditions, possibly including the potential for differentiation towards new cell types, which emphasizes their possible role in the future of tissue engineering.

Apart from morphological alterations, we have found that GCs presented significant changes in expression of genes, belonging to the "cell proliferation", "cell differentiation" and "cell-cell junction organization" ontological groups, during the time of the culture. This large cohort of genes is responsible for processes in which less specialized cells, such as those with regenerative potential, acquire specialized features (functional or structural) specific to the fully developed tissue (Dzafic et al. 2013). Although we could distinguish several patterns of expression changes, we focused on genes characterized by significant up-regulation after day 1 of culture.

First of them, which attracted our attention, was $F Z D 2$ (FRIZZLED CLASS RECEPTOR 2). Expression of FZD2 is detectable in developing ovaries (Zhao et al. 1995). The function of this gene, in physiological condition, is not fully understood, but most likely it is involved in the transmembrane signal transmission. Being a member of the WNT/ $\beta$ catenin signalling pathway, it could play a significant role in developmental processes involving rapid cell proliferation and differentiation. Studies on human GCs suggest that WNT2 can regulate $\beta$-catenin pathways and influence folliculogenesis via FZD receptors (Wang et al. 2009). Additionally, Wang et al. found the highest FZD2 mRNA and protein level in murine oocytes and granulosa cells during the proestrus phase, observing a decrease compared to oestrus to diestrus (Wang et al. 2010). Since all of the collected COCs in our study were in the proestrus stage, increasing 
Table 3 Differentially expressed genes belonging to "tight junction"

\begin{tabular}{|c|c|c|c|c|c|c|c|}
\hline $\begin{array}{l}\text { Official gene } \\
\text { symbol }\end{array}$ & $\begin{array}{l}\text { Fold change D7/ } \\
\text { D1 }\end{array}$ & $\begin{array}{l}\text { Fold change D15/ } \\
\text { D1 }\end{array}$ & $\begin{array}{l}\text { Fold change D30/ } \\
\text { D1 }\end{array}$ & $\begin{array}{l}\text { Adjusted } p \text {. value } \\
\text { D7/D1 }\end{array}$ & $\begin{array}{l}\text { Adjusted } p . \\
\text { value D7/ } \\
\text { D15 }\end{array}$ & $\begin{array}{l}\text { Adjusted } p \text {. } \\
\text { value D7/ } \\
\text { D30 }\end{array}$ & Entrez Gene ID \\
\hline MAP3K5 & 0.2131741 & 0.2378015 & 0.1291998 & 0.005982176 & 0.006818764 & 0.002109835 & 4217 \\
\hline RDX & 0.3062443 & 0.2730968 & 0.1285235 & 0.022738313 & 0.015307731 & 0.003275229 & 5962 \\
\hline AMOTL1 & 0.3434056 & 0.3890707 & 0.4316029 & 0.00439234 & 0.00587025 & 0.007212816 & 154,810 \\
\hline TJP1 & 0.3867947 & 0.3770188 & 0.4099497 & 0.013076762 & 0.010609413 & 0.012479828 & 7082 \\
\hline PPP2R2D & 0.5926332 & 0.5781669 & 0.487322 & 0.050872315 & 0.0395242 & 0.015491178 & 55,844 \\
\hline RAPGEF6 & 0.6687086 & 0.6331767 & 0.4846757 & 0.126146642 & 0.080651203 & 0.018910566 & 51,735 \\
\hline NF2 & 1.2577307 & 1.2366857 & 2.0932489 & 0.376372755 & 0.39067947 & 0.017972215 & 4771 \\
\hline RAC1 & 1.5261235 & 2.052283 & 2.3791522 & 0.190525052 & 0.042547728 & 0.022035289 & 5879 \\
\hline DLG1 & 1.6730427 & 1.8150529 & 2.8723941 & 0.235467987 & 0.155379921 & 0.030426109 & 1739 \\
\hline ITGB1 & 1.8128698 & 1.8176084 & 2.2358846 & 0.024443274 & 0.021895925 & 0.007582053 & 3688 \\
\hline CTTN & 1.8861615 & 1.90003 & 2.0347218 & 0.002853089 & 0.002578576 & 0.001595196 & 2017 \\
\hline PARD6G & 1.9298224 & 2.5969128 & 2.8963465 & 0.137910778 & 0.044816837 & 0.029599738 & 84,552 \\
\hline ACTB & 1.9832451 & 1.6575768 & 2.1164596 & 0.017882382 & 0.039571145 & 0.010613354 & 60 \\
\hline AMOTL2 & 2.2510959 & 1.753789 & 2.2826105 & 0.024608663 & 0.064922906 & 0.01880137 & 51,421 \\
\hline PCNA & 2.3001665 & 2.4071855 & 2.0575267 & 0.017040231 & 0.012566848 & 0.021038161 & 5111 \\
\hline TUBA1A & 2.3402647 & 2.1361513 & 2.3468717 & 0.012904376 & 0.016074104 & 0.010088367 & 7846 \\
\hline LLGL2 & 2.3772916 & 1.6361034 & 1.2549524 & 0.032817316 & 0.138611913 & 0.474636591 & 3993 \\
\hline PRKCZ & 2.4168219 & 3.2661663 & 2.7576197 & 0.068631714 & 0.026079366 & 0.037507268 & 5590 \\
\hline DLG3 & 2.4369791 & 2.551924 & 2.641258 & 0.021918948 & 0.016637516 & 0.013295248 & 1741 \\
\hline INADL & 2.5617955 & 4.536614 & 3.9061643 & 0.040584489 & 0.008377266 & 0.010444005 & 10,207 \\
\hline ACTN4 & 2.5842058 & 2.3022849 & 2.6961029 & 0.001634517 & 0.002166184 & 0.0010491 & 81 \\
\hline RAPGEF2 & 2.699117 & 2.7100365 & 2.220224 & 0.014946734 & 0.012876664 & 0.023381943 & 9693 \\
\hline MAGI1 & 2.8485172 & 2.1931007 & 1.7717224 & 0.022590036 & 0.047934298 & 0.105439274 & 9223 \\
\hline MYH9 & 3.0488704 & 3.3796457 & 3.3547395 & 0.008217194 & 0.005622839 & 0.004944816 & 4627 \\
\hline NEDD4L & 3.4767112 & 4.9176721 & 3.0807669 & 0.009286098 & 0.003901591 & 0.01001863 & 23,327 \\
\hline ACTN1 & 3.6591712 & 3.1534043 & 3.6697117 & 0.000824408 & 0.001090539 & 0.000617487 & 87 \\
\hline PRKAG2 & 4.2205127 & 2.9365982 & 6.3430763 & 0.005788171 & 0.012549391 & 0.00219352 & 51,422 \\
\hline RAB8B & 4.7774458 & 5.8711379 & 4.6905655 & 0.001382959 & 0.000911951 & 0.000986744 & 51,762 \\
\hline MYL9 & 4.8382842 & 3.9460484 & 4.9556207 & 0.005948833 & 0.008193716 & 0.004406837 & 10,398 \\
\hline CCND1 & 5.1728662 & 6.88934 & 14.6717331 & 0.055264324 & 0.030668127 & 0.009914025 & 595 \\
\hline MYH10 & 5.3834258 & 6.30372 & 6.2832283 & 0.075953296 & 0.052311615 & 0.048234636 & 4628 \\
\hline PRKAA2 & 8.2559913 & 10.563523 & 8.1611131 & 0.041708429 & 0.026938194 & 0.034475365 & 5563 \\
\hline JAM2 & 21.0028875 & 13.5493573 & 9.8219339 & 0.015282557 & 0.021967062 & 0.029572679 & 58,494 \\
\hline CLDN11 & 50.2474792 & 59.0106475 & 68.9834723 & 0.01480309 & 0.01157606 & 0.009130531 & 5010 \\
\hline
\end{tabular}

Fold changes, adjusted $p$ values and Entrez Gene ID of differentially expressed genes belonging to the "tight junction" KEGG pathway. Symbols and names of the selected genes are also shown

expression of this gene stays in accordance with this data. Moreover, its ability to regulate cell differentiation has been confirmed by our results of increased gene expression during long-term culture of GCs, underlining possible new functions of FZD2.

The differentially expressed genes analyzed in our study also included VCL (VINCULIN), a gene responsible (in physiological conditions) for the synthesis of a cytoskeletal protein associated with F-actin in the cell membrane (Weller et al. 1990; Silva et al. 2005; Israeli-Rosenberg et al. 2014). It has also been shown that VCL is a significant contributor to the $\mathrm{GC}$ cytoskeleton formation and is associated with the modulation of cytoskeletal proteins, potentially playing a key role in the differentiation of GCs into their particular types during folliculogenesis. So far, studies have shown that rat GCs under the influence of insulin, FSH and chorionic gonadotropin (HCG), increased expression of $V C L$, revealing that it leads to a higher level of steroidogenesis, and lower organization of microfilaments, vinculin and actin (Kranen et al. 1993). Moreover, high expression of $V C L$ in osteoprogenitor cells plays an important role during the proliferation and differentiation of osteoblasts. $V C L$ is critical 


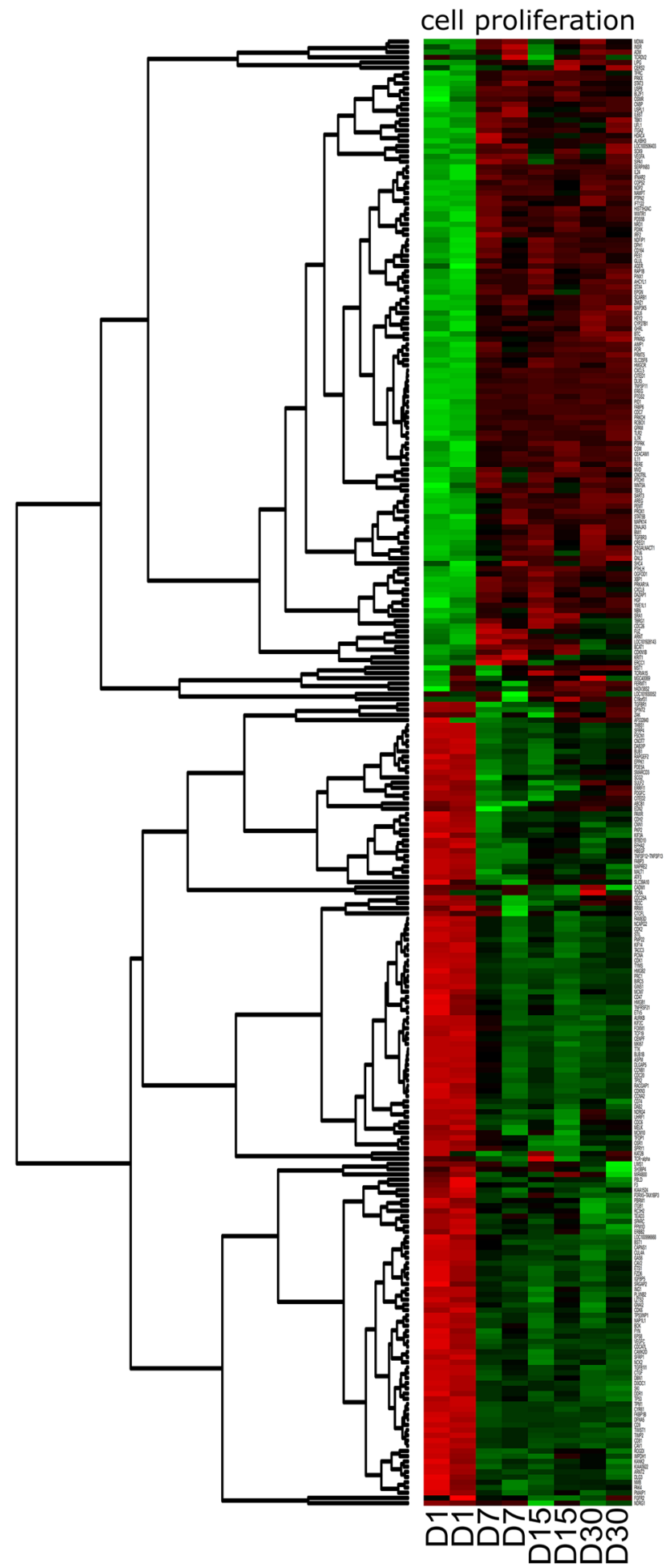

Fig. 3 Heatmap representation of differentially expressed genes belonging to the "cell differentiation" (GO:0030154), "cell proliferation" (GO:0008283) and "cell-cell junction organization" (GO:0045216) gene ontology groups. Arbitrary signal intensity,

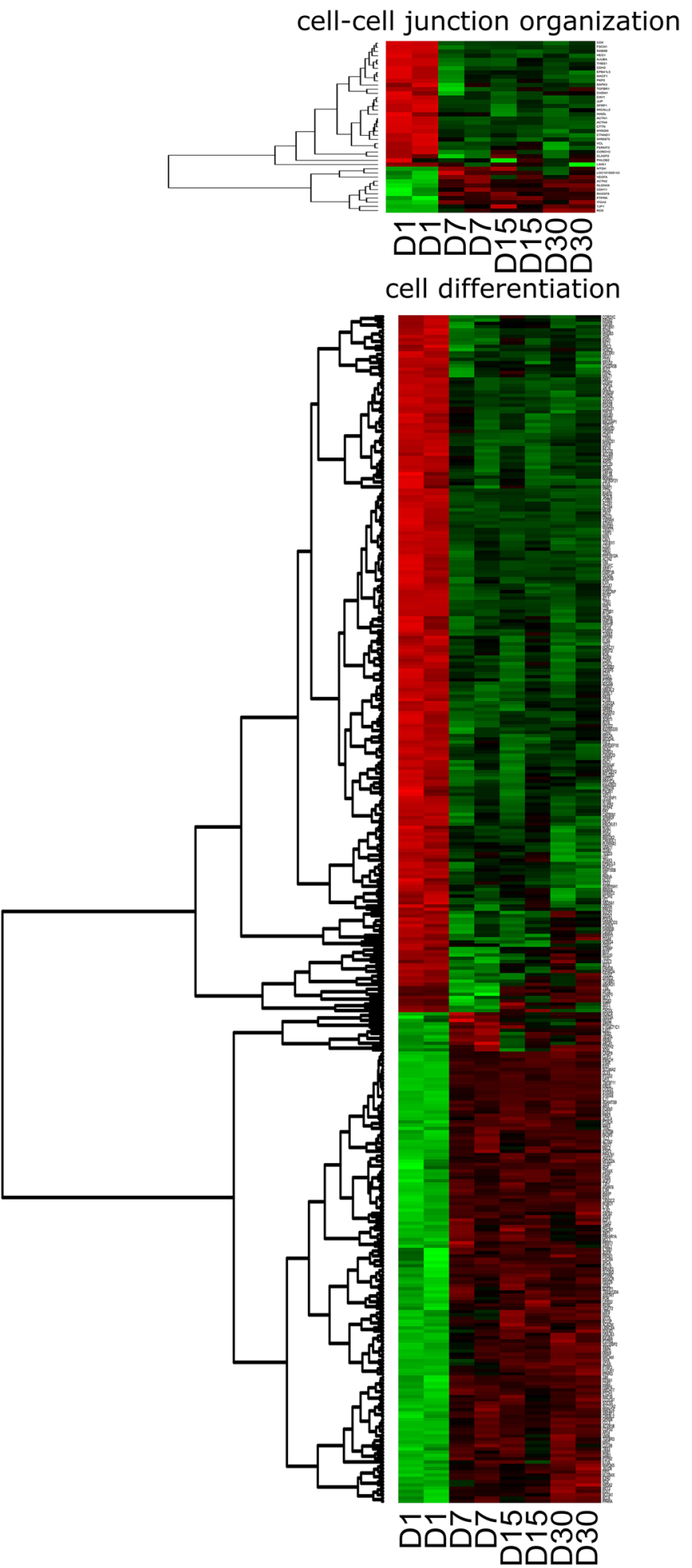

acquired from microarray analysis, is represented by colours (greenhigher expression; red-lower expression). $\log 2$ signal intensity values were resized to Row $Z$ Score scale for all of the genes (from -2 , the lowest expression to +2 , the highest expression) 


\section{D7/D1}

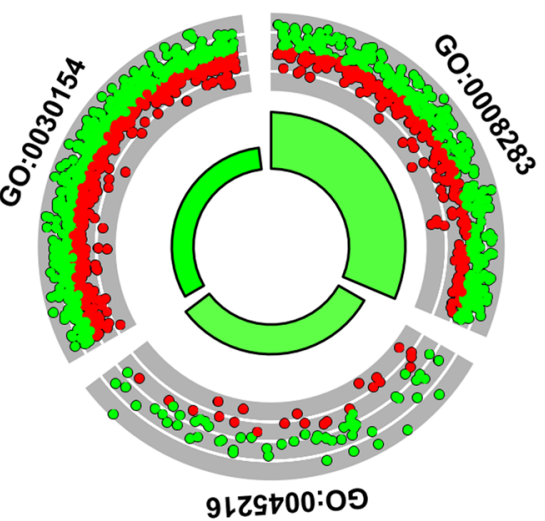

D15/D1

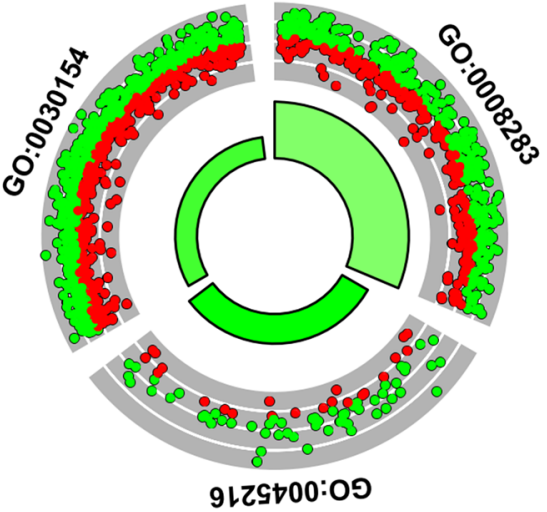

D30/D1

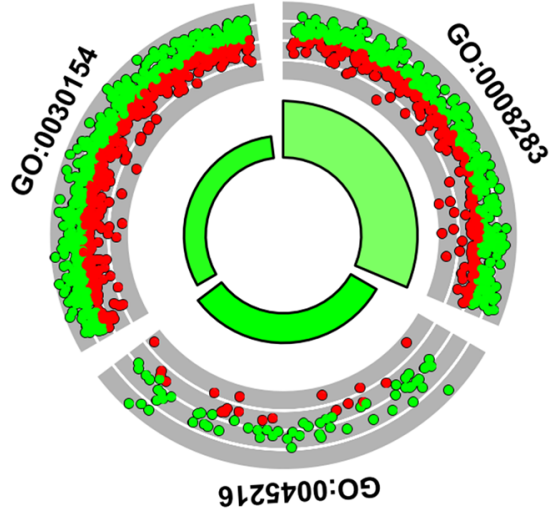

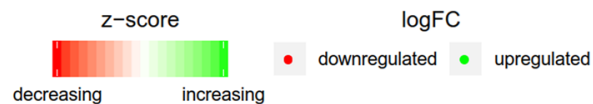

\begin{tabular}{|c|c|}
\hline ID & Description \\
\hline GO:0008283 & cell proliferation \\
\hline GO:0045216 & cell-cell junction organization \\
\hline GO:0030154 & cell differentiation \\
\hline
\end{tabular}

Fig. 4 The circular visualization of the results of gene-annotation enrichment analysis. The outer circle shows a scatter plot for each term of the $\log \mathrm{FC}$ of the assigned genes. The green dots display up- regulation, with the red ones representing down-regulation. The inner circle is a representation of the $z$-scores of respective ontology groups
Fig. 5 The Venn diagram displaying the number of overlapping genes within "cell differentiation" (GO:0030154), "cell proliferation" (GO:0008283) and "cell-cell junction organization" (GO:0045216) gene ontology terms. The diagram also provides the information about the gene expression patterns (up-regulated-green, down-regulated-red), with the intensity of the colours indicating the levels of expression changes

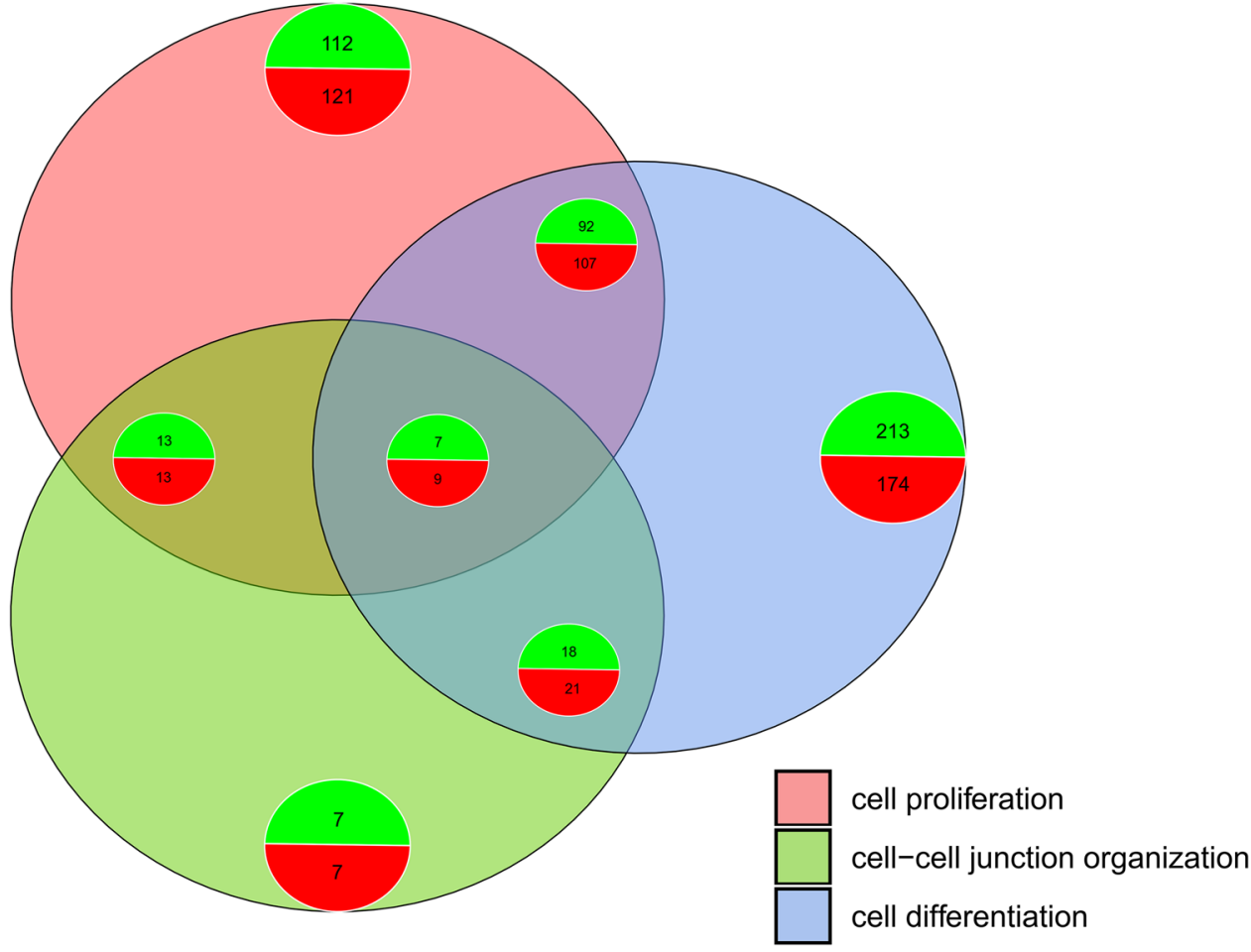

for creating the actin skeleton and regulating cell adhesion during osteodifferentiation (Hong et al. 2010). It is suggested that VCL may be responsible for the final phenotype of GCs (Ben-Ze'ev and Amsterdam 1987). Our observations revealed that VCL may also affect the changes in the cytoskeleton of GCs during their differentiation into other 

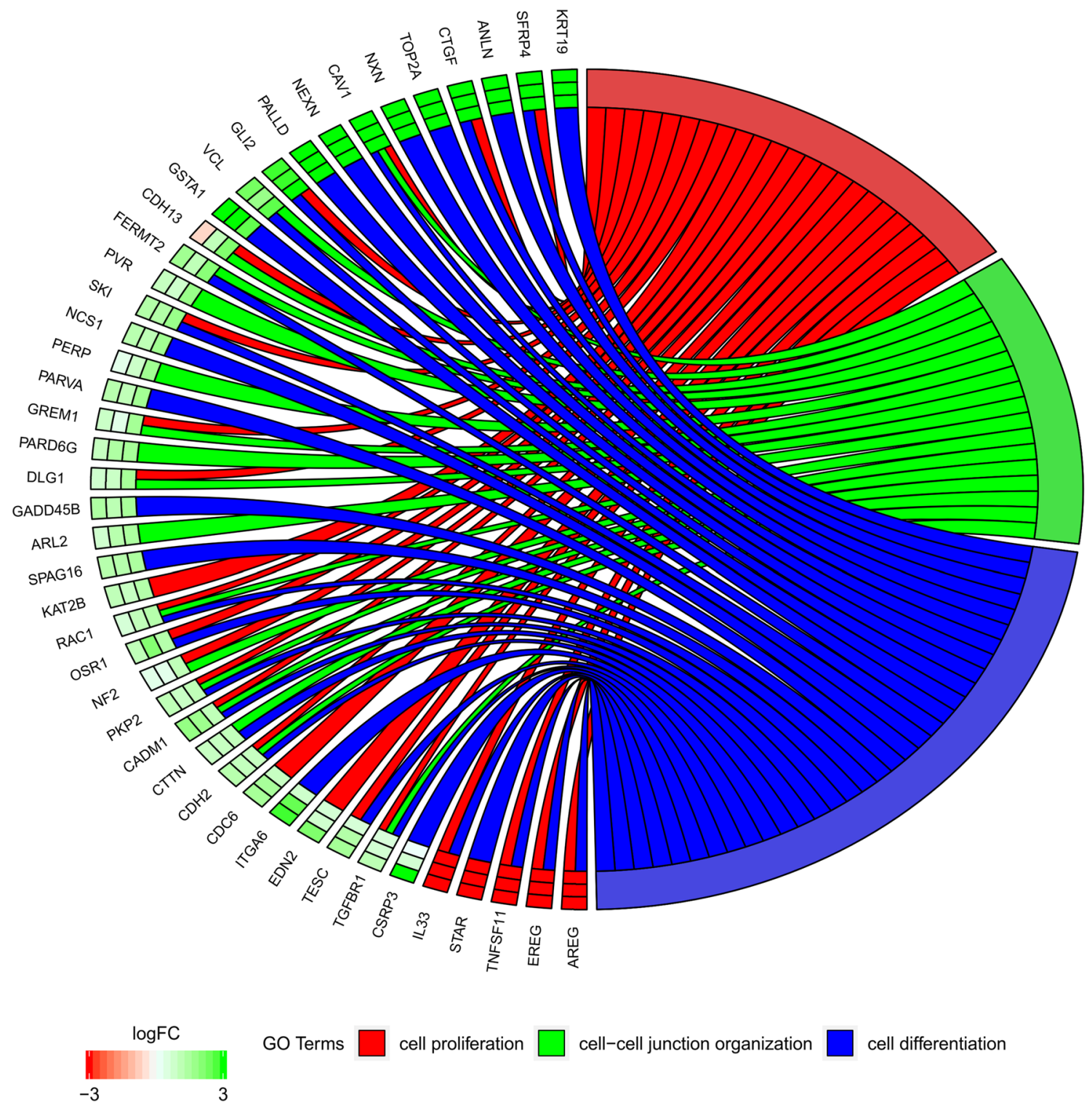

GO Terms

cell proliferation

cell-cell junction organization

cell differentiation

Fig. 6 The representation of the relationship between genes belonging to "cell differentiation" (GO:0030154), "cell proliferation" (GO:0008283), and "cell-cell junction organization" (GO:0045216) gene ontology terms. The ribbons show which gene belongs to which category

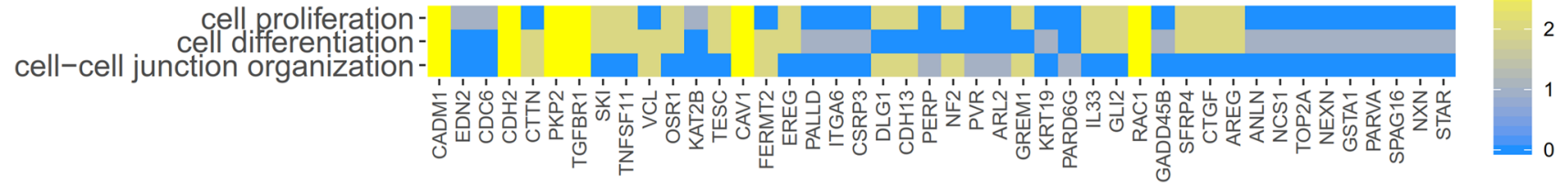

Fig. 7 The heatmap of the relationship between the genes belonging to "cell differentiation" (GO:0030154), "cell proliferation" (GO:0008283), and "cell-cell junction organization" (GO:0045216) gene ontology terms. Biological processes are displayed in rows, with genes presented in columns. Each column is divided into smaller rectangles, with the colouring of the tiles depending on the presence or absence of the gene within the GO term 


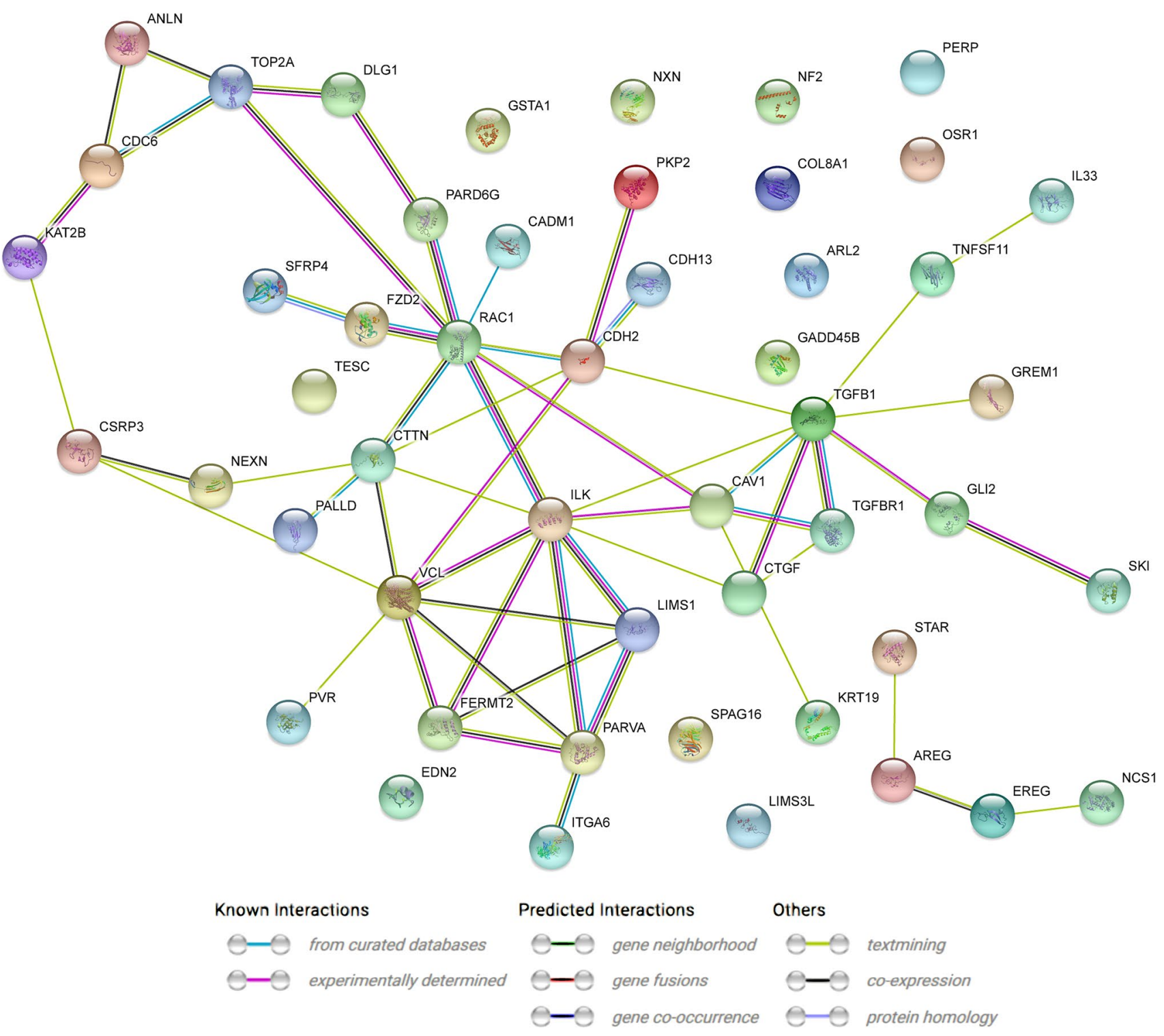

Fig. 8 STRING-generated interaction network between differentially expressed genes chosen for further analysis. The intensity of the edges reflects the strength of the interaction scores

cell types. This assumption was made based on our observation of increased expression of $V C L$ in human GCs during long-term IVC without the addition of hormones (FSH, HCG, and differentiation stimulating factors).

Another gene that is also related to the developmental processes, is the SKI gene (ONCOGENE SK). Multiple studies of Kim et al., performed on rats, presented the evidence that $S K I$ expression is observed in atretic follicles, but not in preovulatory follicles. This suggests that the gene can play a role in apoptosis of the GCs. On the other hand, granulosa cells undergo substantial differentiation towards luteal cells, which points out the role of this gene in their transformation (Kim et al. 2012). This note, together with our observation of increased expression, suggests that $S K I$ can also play a role in differentiation of GCs towards other cell types. Previous data describes the $S K I$ expression in the embryo during the development of blood vessels-especially the aorta, and suggests that this gene is involved in the regulation of TGF- $\beta$ signalling in arterial media during embryonic development (Doyle et al. 2012). This information justifies the recent finding of Basini et al., who presented the evidence that GCs cultured in endothelial culture medium (EBM-2) gained functional and phenotypic characteristics of endothelial cells (Basini et al. 2016).

Cell proliferation depends partly on proper cell communication. One of the genes associated with these processes is $C D H 2$ (CADHERIN 2). It belongs to the family of genes encoding calcium ion-dependent adhesion proteins. Studies 


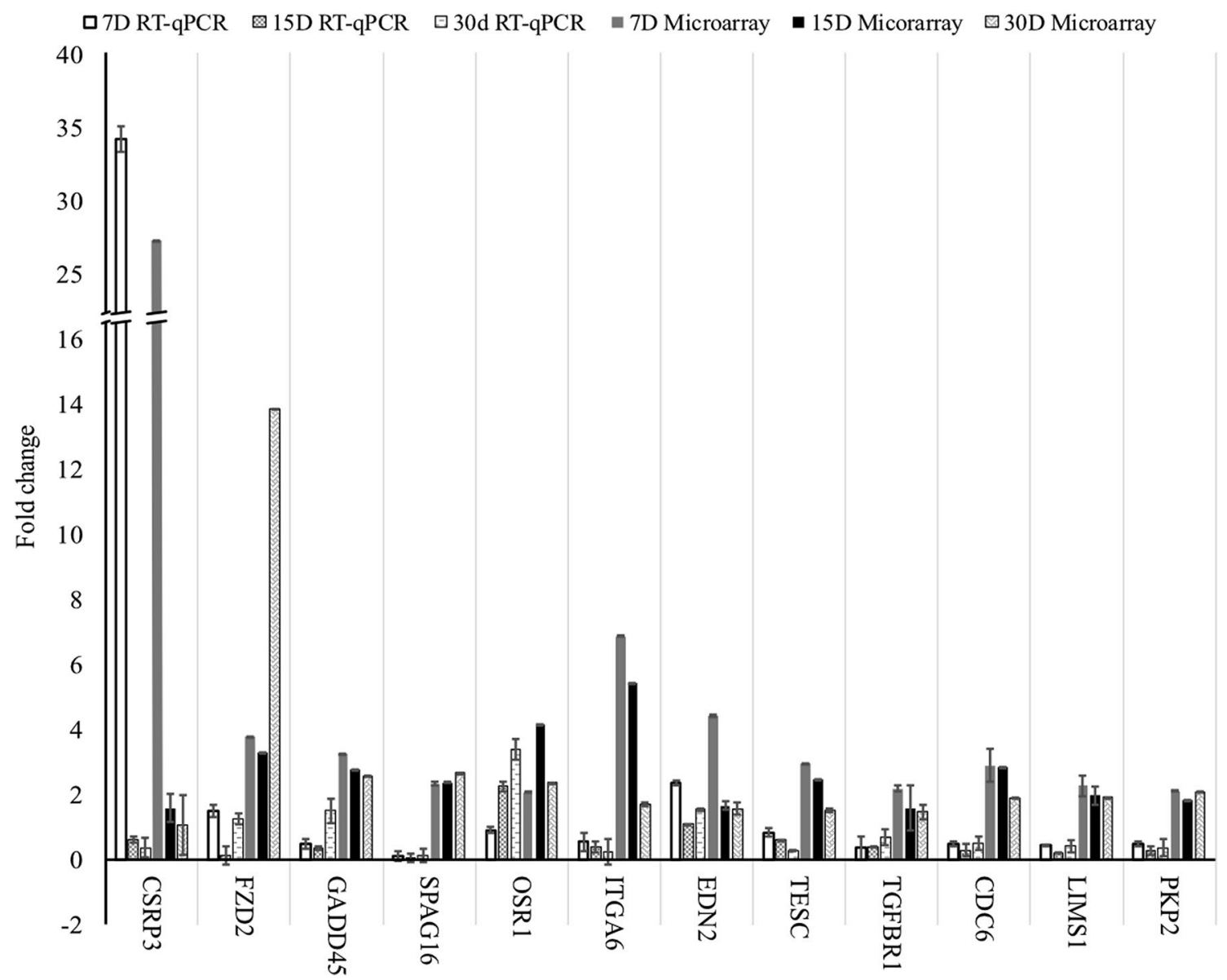

Fig. 9 Results of the RT-qPCR validation presented in the form of a bar chart, with comparisons to the results obtained through the microarray analysis. All the values presented are the relative changes in gene expression, compared to Day 1 of primary culture. $D$ day of culture

Fig. 10 Changes in morphology of granulosa cells during the long-term culture

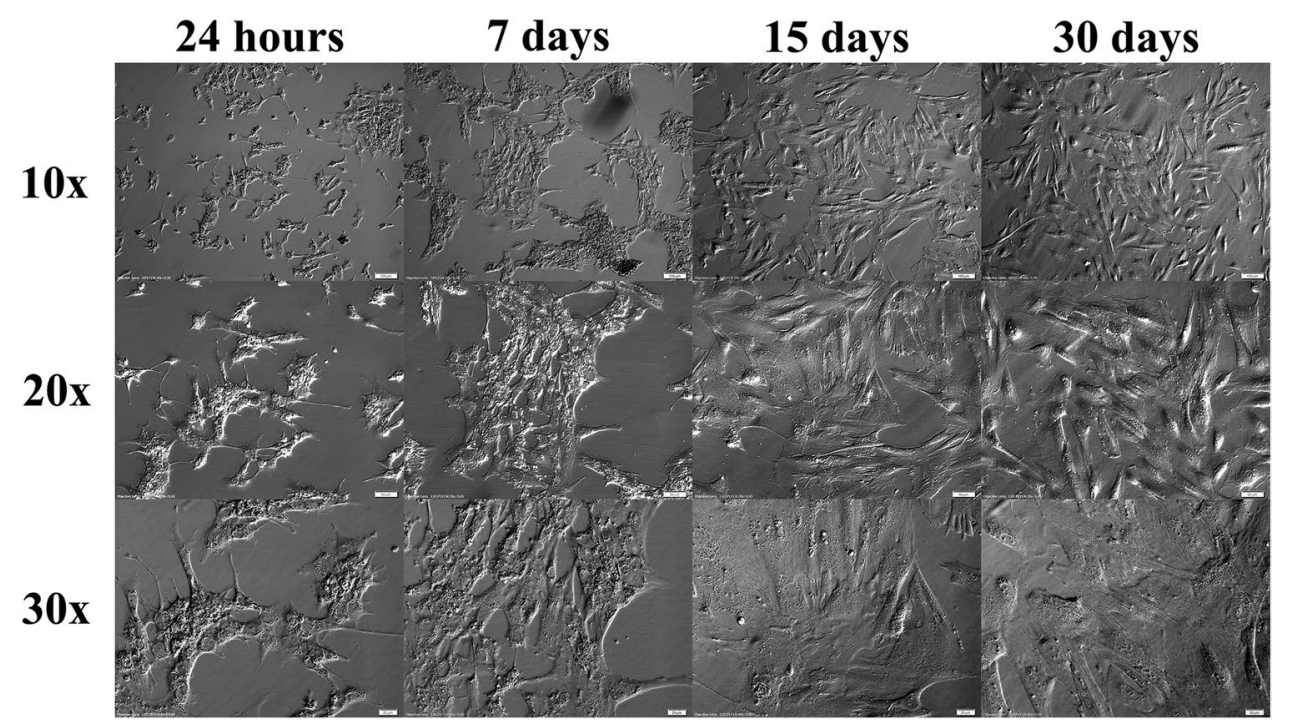

on hamster ovarian follicles showed that, while expression of $\mathrm{CDH} 1$ is restricted only to oocytes during neonatal ovary development, $\mathrm{CDH} 2$ is present in the GCs of growing follicles (Wang and Roy 2010). Additionally, cadherin 2, together with vimentin, is a marker of GCs mesenchymal origin. Our observation of increased expression of $\mathrm{CDH} 2$ 
during long-term IVC proves that GCs maintain their mesenchymal character, without shifting towards epithelial phenotype (Yenuganti and Vanselow 2017). In spite of not knowing the exact direction of GCs differentiation, it is established that $\mathrm{CDH} 2$ also participates in the developmental process of the nervous system and formation of cartilage and bone (Chung et al. 2014). Up-regulated expression of the above gene may suggest the potential of GC differentiation towards osteoblasts. Moreover, high expression of the $K$ (lysine) Acetyltransferase $2 B$ (KAT2B) gene may also indicate the differentiational potential of the GCs, since it activates the RUNX2 transcription factor, which promotes mesenchymal stem cell differentiation towards osteoblasts (Dzafic et al. 2014). The above gene is responsible for the production of nuclear proteins that bind many factors, characterizing cell growth and differentiation (Yang et al. 1996).

Another gene associated with the cellular communication is NCS1 (FREQUENIN). Signal transmission can take place in multiple ways, including those that involve neurotransmitters (Hancock 2017). The demonstrated study suggests that expression of the NCS1 gene (FREQUENIN) is increasing during long-term IVC. This gene encodes a protein that acts as a calcium ion sensor, modulating synaptic and secretory activity (De Castro et al. 1995). Mc Ferran et al. suggests that $N C S 1$ is primarily expressed in neuroendocrine cells and may be responsible for the regulation of neurosecretion (Burgoyne and Weiss 2001). Although we could not find direct evidence, up-regulated expression of this gene may indicate its role in GCs differentiation towards neuronal cells. This would stay in accordance with results of Kossowska-Tomaszczuk, who proved that GCs can acquire features of neuroblasts under influence of the differentiating factors.

Cellular viability and proliferation are associated with transforming growth factor beta (TGF- $\beta$ ) (Juengel et al. 2004). TGF- $\beta$ exhibits a variety of biological activities and is a potential regulator of cell proliferation and differentiation (Tripurani et al. 2013; Ribeiro et al. 2017). Referring the literature data to the obtained results, it may be noted that these genes may also influence proliferation and cell viability during in vitro culture. Under physiological conditions, GCs form a corpus luteum, which transforms into corpus albicans after around 10 days. Under in vitro culture conditions, these cells remained viable up to day 30 of culture. Expression of the mentioned genes was also maintained. Studies show that different types of TGF- $\beta$ receptors (TGFBR) exist on the cell surface. TGFBR are either transmembrane receptors or cytoplasmic tyrosine kinases (Kingsley 1994). We found increased expression of $T G F B$ and TGFBRI (TYPE I TGF- $\beta$ RECEPTOR) during the time of IVC. This receptor is involved in the induction of some genes involved in the cell-matrix interaction (Ebner et al. 1993). In the pig model, Paradis et al. clearly indicated that
TGF- $\beta$ and its receptors play an important role during ovulation. These factors support the normal/correct action of BMP15 and BMPR1B (Paradis et al. 2009). Moreover, since it is a very strong oncogene, TGFBRI promoted granulosa cell tumour development in mice (Gao et al. 2017). Overexpression of TGFBRl also contributes to morphological, hormonal and molecular changes in GCs (Gao et al. 2016). Additionally, TGFBRl is a gene characterizing human placental mesenchymal stem cells (Abumaree et al. 2013). The presented studies suggest that the above genes play a key role not only in the proliferation of GCs under physiological conditions but also during cell proliferation and differentiation during long-term in vitro culture.

Apart from genes which can be directly linked to the physiology of GCs, we analyzed those, whose role in folliculogenesis and/or cells differentiation has not yet been described. Based on available data, we tried to interpret our results and find the potential role of described genes in the process of granulosa cell differentiation.

Among them was PARVA (PARVIN ALPHA), increased expression of which has so far been detected in the heart, skeletal muscles, kidneys and liver (Korenbaum et al. 2001). Parvin belongs to the family of proteins involved in the integration of proteins which is involved in the intracellular pathways responsible for the dynamics of the actin cytoskeleton and cell viability. Parvin forms a complex with ILK (Integrin-linked Kinase) and LIMS1 (LIM And Senescent Cell Antigen-Like Domains 1) proteins, playing a key role in cell's protection against the apoptotic process, promoting cell survival and viability (Fukuda et al. 2003). Interestingly, we have also noted the up-regulated expression of LIMSI. Due to the lack of data describing the role of both genes in the physiology of GCs, we can only assume that this complex may also promote prolonged proliferation and viability of GCs in long-term IVC, as well as serve as an intermediate in $\mathrm{GC}$ alterations.

According to recently presented data, GCs can differentiate into few cell types, including chondrocytes (Dzafic et al. 2013; Kossowska-Tomaszczuk and De Geyter 2013; Hummitzsch et al. 2015). Among our analyzed genes, the candidate that could trigger the transition towards chondrocyte lineage is FERMT2, also called Kindlin 2. Our hypothesis was made based on the fact that FERMT2 is responsible for regulating the process of chondrocyte differentiation and chondrogenesis. Lack of this gene inhibits TGFB1-induced Smad2 phosphorylation and chondrocyte differentiation (Wu et al. 2015). Consequently, observations of $\mathrm{Wu}$ et al. showed that mice lacking FERMT2 in mesenchymal progenitor cells exhibited high neonatal mortality, chondrodysplasia, and loss of cranial vaulting. Additionally, FERMT2 is regarded as an integrator and activator, participating in the induction of epithelial-mesenchymal transition (EMT) during embryogenesis and 
ovulation (Ma et al. 2008). It has been suggested that during ovulation, GCs change their epithelial character and undergo EMT (Yang et al. 2014). The last theory stays in accordance with the outcome of our study, where increased expression of FERMT2 correlated with the change in GC morphology from epithelial-like to fibroblast-like. In addition, this gene may be responsible for the process of GC differentiation into particular cell types characteristic for mature Graafian follicle (Kossowska-Tomaszczuk and De Geyter 2013).

Some of the differentially expressed genes belonging to the studied ontology groups also confirmed the possibility of GC differentiation into osteoblasts. We can suppose that the transcription factor GLI2 (GLI-KRUPPEL FAMILY MEM$B E R$ 2) can be one of them, since it is responsible for the correct development of the spine (Bertolacini et al. 2012). Mutations in the GLI2 gene cause defects in the development of the skeleton. In addition, GLI2 has been shown to play a crucial role in regulating BMP-2 protein expression during mesenchymal stem cell differentiation toward osteoblast (Zhao et al. 2006). Similarly, a significant change in expression of COL5AI (COLLAGEN TYPE V ALPHA 1) has attracted our attention. This gene is thought to be responsible for the proper synthesis of collagen present in the skin, tendons, and bones. Mutations in COL1Al were shown to be associated with osteoporosis and other bones disorders (Viguet-Carrin et al. 2006). Although we could not find direct evidence for the involvement of the above genes in the process of osteodifferentiation, we consider this observation as valuable, indicating the possible direction of GC differentiation.

The presented analysis suggests that many genes specific for cell differentiation and proliferation processes show high changes in expression during the long-term primary in vitro culture of the GCs. GCs express both-genes specific to differentiation processes and genes that are usually proprietary to other cell types. It can be assumed that GCs lose their primary function in long-term primary culture and gain new features and qualities. Thus, the above studies suggest the ability of GCs to differentiate towards a range of distinct types of cells and tissues. It is therefore envisaged that a stable culture of muscle cells and/or osteoblasts can be obtained under the influence of specific differentiation factors. The studies presented are intended to show the usefulness of GCs, which are usually only treated as the remnant material of the IVF fertilization. Due to the observed changes in the GCs transcriptome, it may be possible to use these cells in the broadly understood tissue engineering.

Acknowledgements Publication of this article was made possible by Grant number 2014/15/B/NZ7/00999 from the Polish National Centre of Science, UMO-2012/07/N/NZ5/00069 from the Polish National Centre of Science and Grant number 502-01-02227367-08414 from Poznan University of Medical Sciences.

\section{Compliance with ethical standards}

Informed consent This study has been approved with resolution 558/17 by Bioethical Committee. All participants gave written informed consent to research. Informed consent was obtained from all individual participants included in the study.

Ethical standards All procedures performed in studies involving human participants were in accordance with the ethical standards of the institutional and/or national research committee and with the 1964 Helsinki declaration and its later amendments or comparable ethical standards.

Conflict of interest The authors declare that they have no conflict of interest.

Open Access This article is distributed under the terms of the Creative Commons Attribution 4.0 International License (http://creativeco mmons.org/licenses/by/4.0/), which permits unrestricted use, distribution, and reproduction in any medium, provided you give appropriate credit to the original author(s) and the source, provide a link to the Creative Commons license, and indicate if changes were made.

\section{References}

Abumaree MH, Al Jumah MA, Kalionis B et al (2013) Phenotypic and functional characterization of mesenchymal stem cells from chorionic villi of human term placenta. Stem Cell Rev Rep 9:16-31. https://doi.org/10.1007/s12015-012-9385-4

Anderson RA, Sciorio R, Kinnell H et al (2009) Cumulus gene expression as a predictor of human oocyte fertilisation, embryo development and competence to establish a pregnancy. Reproduction 138:629-637. https://doi.org/10.1530/REP-09-0144

Antosik P, Kempisty B, Jackowska M et al (2010) Assessment of transcript and protein levels contributing to cell cycle control and gap junction connections in morphologically variable groups of porcine cumulus-oocyte complexes. Vet Med (Praha) 55:512-521

Avior Y, Sagi I, Benvenisty N (2016) Pluripotent stem cells in disease modelling and drug discovery. Nat Rev Mol Cell Biol 17:170182. https://doi.org/10.1038/nrm.2015.27

Basini G, Falasconi I, Bussolati S et al (2016) Swine granulosa cells show typical endothelial cell characteristics. Reprod Sci 23:630 637. https://doi.org/10.1177/1933719115612130

Ben-Ze'ev A, Amsterdam A (1987) In vitro regulation of granulosa cell differentiation. Involvement of cytoskeletal protein expression. J Biol Chem 262:5366-5376

Bertolacini C, Ribeiro-Bicudo L, Petrin A et al (2012) Clinical findings in patients with GLI2 mutations-phenotypic variability. Clin Genet 81:70-75. https://doi.org/10.1111/j.1399-0004.2010.01606 . $\mathrm{x}$

Brevini TAL, Pennarossa G, Rahman MM et al (2014) Morphological and molecular changes of human granulosa cells exposed to 5-azacytidine and addressed toward muscular differentiation. Stem Cell Rev Rep 10:633-642. https://doi.org/10.1007/s12015-014-9521-4

Budna J, Celichowski P, Karimi P et al (2017) Does porcine oocytes maturation in vitro is regulated by genes involved in transforming growth factor beta receptor signaling pathway? Adv Cell Biol 5:1-14. https://doi.org/10.1515/acb-2017-0001

Burgoyne RD, Weiss JL (2001) The neuronal calcium sensor family of $\mathrm{Ca}^{2+}$-binding proteins. Biochem J 353:1-12

Chachuła A, Kranc W, Budna J et al (2016) The differentiation of mammalian ovarian granulosa cells living in the shadow of 
cellular developmental capacity. J Biol Regul Homeost Agents 30:627-634

Chomczynski P, Sacchi N (1987) Single-step method of RNA isolation by acid guanidinium thiocyanate-phenol-chloroform extraction. Anal Biochem 162:156-159. https://doi.org/10.1016/00032697(87)90021-2

Chung F-Z, Sahasrabuddhe AA, Ma K et al (2014) Fbxo45 inhibits calcium-sensitive proteolysis of $\mathrm{N}$-cadherin and promotes neuronal differentiation. J Biol Chem 289:28448-28459. https://doi. org/10.1074/jbc.M114.561241

De Castro E, Nef S, Fiumelli H et al (1995) Regulation of rhodopsin phosphorylation by a family of neuronal calcium sensors. Biochem Biophys Res Commun 216:133-140

Doyle AJ, Doyle JJ, Bessling SL et al (2012) Mutations in the TGF- $\beta$ repressor SKI cause Shprintzen-Goldberg syndrome with aortic aneurysm. Nat Genet 44:1249-1254. https://doi.org/10.1038/ ng. 2421

Dumesic DA, Meldrum DR, Katz-Jaffe MG et al (2015) Oocyte environment: follicular fluid and cumulus cells are critical for oocyte health. Fertil Steril 103:303-316. https://doi.org/10.1016/j.fertn stert.2014.11.015

Dzafic E, Stimpfel M, Virant-Klun I (2013) Plasticity of granulosa cells: on the crossroad of stemness and transdifferentiation potential. J Assist Reprod Genet 30:1255-1261. https://doi.org/10.1007/ s10815-013-0068-0

Dzafic E, Stimpfel M, Novakovic S et al (2014) Expression of mesenchymal stem cells-related genes and plasticity of aspirated follicular cells obtained from infertile women. Biomed Res Int 2014:508216. https://doi.org/10.1155/2014/508216

Ebner R, Chen RH, Shum L et al (1993) Cloning of a type I TGF-beta receptor and its effect on TGF-beta binding to the type II receptor. Science 260:1344-1348

Fukuda T, Chen K, Shi X, Wu C (2003) PINCH-1 is an obligate partner of integrin-linked kinase (ILK) functioning in cell shape modulation, motility, and survival. J Biol Chem 278:51324-51333. https ://doi.org/10.1074/jbc.M309122200

Gao F, Zhang J, Wang X et al (2014) Wt1 functions in ovarian follicle development by regulating granulosa cell differentiation. Hum Mol Genet 23:333-341. https://doi.org/10.1093/hmg/ddt423

Gao Y, Vincent DF, Davis AJ et al (2016) Constitutively active transforming growth factor $\beta$ receptor 1 in the mouse ovary promotes tumorigenesis. Oncotarget 7:40904-40918. https://doi. org/10.18632/oncotarget.10149

Gao Y, Fang X, Vincent DF et al (2017) Disruption of postnatal folliculogenesis and development of ovarian tumor in a mouse model with aberrant transforming growth factor beta signaling. Reprod Biol Endocrinol 15:94. https://doi.org/10.1186/s1295 8-017-0312-z

Hancock JT (2017) Cell signalling. Oxford University Press, Oxford

Hong D, Chen H-X, Yu H-Q et al (2010) Morphological and proteomic analysis of early stage of osteoblast differentiation in osteoblastic progenitor cells. Exp Cell Res 316:2291-2300. https://doi. org/10.1016/j.yexcr.2010.05.011

Huang DW, Sherman BT, Tan Q et al (2007) DAVID bioinformatics resources: expanded annotation database and novel algorithms to better extract biology from large gene lists. Nucleic Acids Res 35:W169-W175. https://doi.org/10.1093/nar/gkm415

Hummitzsch K, Anderson RA, Wilhelm D et al (2015) Stem cells, progenitor cells, and lineage decisions in the ovary. Endocr Rev 36:65-91. https://doi.org/10.1210/er.2014-1079

Israeli-Rosenberg S, Manso AM, Okada H, Ross RS (2014) Integrins and integrin-associated proteins in the cardiac myocyte. Circ Res 114:572-586. https://doi.org/10.1161/CIRCRESAHA.114.301275

Jankowski M, Dyszkiewicz-Konwińska M, Budna J et al (2018) The differentiation and transdifferentiation of epithelial cells in vitro-is it a new strategy in regenerative biomedicine? Med J Cell Biol 6:27-32. https://doi.org/10.2478/acb-2018-0005

Juengel JL, Bibby AH, Reader KL et al (2004) The role of transforming growth factor-beta (TGF-beta) during ovarian follicular development in sheep. Reprod Biol Endocrinol 2:78. https://doi. org/10.1186/1477-7827-2-78

Kempisty B, Ziółkowska A, Ciesiółka S et al (2014a) Study on connexin gene and protein expression and cellular distribution in relation to real-time proliferation of porcine granulosa cells. J Biol Regul Homeost Agents 28:625-635

Kempisty B, Ziółkowska A, Piotrowska H et al (2014b) Expression and cellular distribution of cyclin-dependent kinase $4(\mathrm{Cdk} 4)$ and connexin $43(\mathrm{Cx} 43)$ in porcine oocytes before and after in vitro maturation. Acta Vet Hung 62:84-95. https://doi.org/10.1556/ AVet.2013.039

Kempisty B, Wojtanowicz-Markiewicz K, Ziółkowska A et al (2015) Association between progesterone and estradiol-17beta treatment and protein expression of pgr and PGRMC1 in porcine luminal epithelial cells: a real-time cell proliferation approach. J Biol Regul Homeost Agents 29:39-50

Kim H, Kim DH, Park SB et al (2012) Induction of ski protein expression upon luteinization in rat granulosa cells. Asian Aust J Anim Sci 25:635-641. https://doi.org/10.5713/ajas.2011.11336

Kingsley DM (1994) The TGF-beta superfamily: new members, new receptors, and new genetic tests of function in different organisms. Genes Dev 8:133-146

Korenbaum E, Olski TM, Noegel AA (2001) Genomic organization and expression profile of the parvin family of focal adhesion proteins in mice and humans. Gene 279:69-79

Kossowska-Tomaszczuk K, De Geyter C (2013) Cells with stem cell characteristics in somatic compartments of the ovary. Biomed Res Int 2013:310859. https://doi.org/10.1155/2013/310859

Kossowska-Tomaszczuk K, De Geyter C, De Geyter M et al (2009) The multipotency of luteinizing granulosa cells collected from mature ovarian follicles. Stem Cells 27:210-219. https://doi.org/10.1634/ stemcells.2008-0233

Kossowska-Tomaszczuk K, Pelczar P, Güven S et al (2010) A novel three-dimensional culture system allows prolonged culture of functional human granulosa cells and mimics the ovarian environment. Tissue Eng Part A 16:2063-2073. https://doi.org/10.1089/ ten.TEA.2009.0684

Kranc W, Chachuła A, Bryja A et al (2016) Selected molecular and physiological aspects of mammalian ovarian granulosa cells in primary culture. Med Weter 72:723-727. https://doi.org/10.21521 /mw.5606

Kranc W, Brązert M, Ożegowska K et al (2017a) Expression profile of genes regulating steroid biosynthesis and metabolism in human ovarian granulosa cells-a primary culture approach. Int J Mol Sci 18:2673. https://doi.org/10.3390/ijms18122673

Kranc W, Budna J, Kahan R et al (2017b) Molecular basis of growth, proliferation, and differentiation of mammalian follicular granulosa cells. J Biol Regul Homeost Agents 31:1-8

Kranc W, Celichowski P, Budna J et al (2017c) Positive regulation of macromolecule metabolic process belongs to the main mechanisms crucial for porcine oocytes maturation. Adv Cell Biol 5:15-31. https://doi.org/10.1515/acb-2017-0002

Kranc W, Jankowski M, Budna J et al (2018) Amino acids metabolism and degradation is regulated during porcine oviductal epithelial cells (OECs) primary culture in vitro-a signaling pathways activation approach. Med J Cell Biol 6:18-26. https://doi. org/10.2478/acb-2018-0004

Kranen RW, Overes HW, Kloosterboer HJ, Poels LG (1993) The expression of cytoskeletal proteins during the differentiation of rat granulosa cells. Hum Reprod 8:24-29 
Luo W, Brouwer C (2013) Pathview: an R/Bioconductor package for pathway-based data integration and visualization. Bioinformatics 29:1830-1831. https://doi.org/10.1093/bioinformatics/btt285

Ma Y-Q, Qin J, Wu C, Plow EF (2008) Kindlin-2 (Mig-2): a coactivator of $\beta 3$ integrins. J Cell Biol 181:439-446. https://doi. org/10.1083/jcb.200710196

Niswender GD, Juengel JL, Silva PJ et al (2000) Mechanisms controlling the function and life span of the corpus luteum. Physiol Rev 80:1-29. https://doi.org/10.1152/physrev.2000.80.1.1

Oki Y, Ono H, Motohashi T et al (2012) Dedifferentiated follicular granulosa cells derived from pig ovary can transdifferentiate into osteoblasts. Biochem J 447:239-248. https://doi.org/10.1042/ BJ20120172

Paradis F, Novak S, Murdoch GK et al (2009) Temporal regulation of BMP2, BMP6, BMP15, GDF9, BMPR1A, BMPR1B, BMPR2 and TGFBR1 mRNA expression in the oocyte, granulosa and theca cells of developing preovulatory follicles in the pig. Reproduction 138:115-129. https://doi.org/10.1530/REP-08-0538

Quinn MCJ, McGregor SB, Stanton JL et al (2006) Purification of granulosa cells from human ovarian follicular fluid using granulosa cell aggregates. Reprod Fertil Dev 18:501-508

Ribeiro A, Freitas C, Matos L et al (2017) Age-related expression of TGF beta family receptors in human cumulus oophorus cells. J Assist Reprod Genet 34:1121-1129. https://doi.org/10.1007/s1081 5-017-0930-6

Russell DL, Gilchrist RB, Brown HM, Thompson JG (2016) Bidirectional communication between cumulus cells and the oocyte: old hands and new players? Theriogenology 86:62-68. https://doi. org/10.1016/j.theriogenology.2016.04.019

Rybska M, Knap S, Jankowski M et al (2018) Characteristic of factors influencing the proper course of folliculogenesis in mammals. Med J Cell Biol 6:33-38. https://doi.org/10.2478/acb-2018-0006

Silva JRV, van den Hurk R, van Tol HTA et al (2005) Expression of growth differentiation factor 9 (GDF9), bone morphogenetic protein 15 (BMP15), and BMP receptors in the ovaries of goats. Mol Reprod Dev 70:11-19. https://doi.org/10.1002/mrd.20127

Stocco C, Telleria C, Gibori G (2007) The molecular control of corpus luteum formation, function, and regression. Endocr Rev 28:117149. https://doi.org/10.1210/er.2006-0022

Tanghe S, Van Soom A, Nauwynck H et al (2002) Minireview: functions of the cumulus oophorus during oocyte maturation, ovulation, and fertilization. Mol Reprod Dev 61:414-424. https://doi. org/10.1002/mrd.10102

Tripurani SK, Cook RW, Eldin KW, Pangas SA (2013) BMP-specific SMADs function as novel repressors of PDGFA and modulate its expression in ovarian granulosa cells and tumors. Oncogene 32:3877-3885. https://doi.org/10.1038/onc.2012.392

Truman AM, Tilly JL, Woods DC (2017) Ovarian regeneration: the potential for stem cell contribution in the postnatal ovary to sustained endocrine function. Mol Cell Endocrinol 445:74-84. https ://doi.org/10.1016/j.mce.2016.10.012

Tsafriri A, Channing CP (1975) An inhibitory influence of granulosa cells and follicular fluid upon porcine oocyte meiosis in vitro. Endocrinology 96:922-927. https://doi.org/10.1210/ endo-96-4-922

Viguet-Carrin S, Garnero P, Delmas PD (2006) The role of collagen in bone strength. Osteoporos Int 17:319-336. https://doi. org/10.1007/s00198-005-2035-9

von Mering C, Jensen LJ, Snel B et al (2004) STRING: known and predicted protein-protein associations, integrated and transferred across organisms. Nucleic Acids Res 33:D433-D437. https://doi. org/10.1093/nar/gki005

Walter W, Sánchez-Cabo F, Ricote M (2015) GOplot: an R package for visually combining expression data with functional analysis. Bioinformatics 31:2912-2914. https://doi.org/10.1093/bioinforma tics/btv300

Wang C, Roy SK (2010) Expression of E-cadherin and N-cadherin in perinatal hamster ovary: possible involvement in primordial follicle formation and regulation by follicle-stimulating hormone. Endocrinology 151:2319-2330. https://doi.org/10.1210/ en.2009-1489

Wang H-X, Tekpetey FR, Kidder GM (2009) Identification of WNT/ beta-CATENIN signaling pathway components in human cumulus cells. Mol Hum Reprod 15:11-17. https://doi.org/10.1093/moleh r/gan070

Wang SB, Xing BS, Yi L et al (2010) Expression of Frizzled 2 in the mouse ovary during oestrous cycle. J Anim Physiol Anim Nutr (Berl) 94:437-445. https://doi.org/10.111 1/j.1439-0396.2009.00927.x

Weller PA, Ogryzko EP, Corben EB et al (1990) Complete sequence of human vinculin and assignment of the gene to chromosome 10. Proc Natl Acad Sci USA 87:5667-5671

Wu C, Jiao H, Lai Y et al (2015) Kindlin- 2 controls TGF- $\beta$ signalling and Sox 9 expression to regulate chondrogenesis. Nat Commun 6:7531. https://doi.org/10.1038/ncomms8531

Yang X-J, Ogryzko VV, Nishikawa J et al (1996) A p300/CBP-associated factor that competes with the adenoviral oncoprotein E1A. Nature 382:319-324. https://doi.org/10.1038/382319a0

Yang M, Du J, Lu D et al (2014) Increased expression of kindlin 2 in luteinized granulosa cells correlates with androgen receptor level in patients with polycystic ovary syndrome having hyperandrogenemia. Reprod Sci 21:696-703. https://doi.org/10.1177/19337 19113512536

Yenuganti VR, Vanselow J (2017) Cultured bovine granulosa cells rapidly lose important features of their identity and functionality but partially recover under long-term culture conditions. Cell Tissue Res 368:397-403. https://doi.org/10.1007/s00441-017-2571-6

Zhao Z, Lee CC, Baldini A, Caskey CT (1995) A human homologue of the drosophila polarity gene frizzled has been identified and mapped to 17q21.1. Genomics 27:370-373. https://doi. org/10.1006/geno.1995.1060

Zhao M, Qiao M, Harris SE et al (2006) The zinc finger transcription factor Gli2 mediates bone morphogenetic protein 2 expression in osteoblasts in response to hedgehog signaling. Mol Cell Biol 26:6197-6208. https://doi.org/10.1128/MCB.02214-05

\section{Affiliations}

\section{Wiesława Kranc ${ }^{1} \cdot$ Maciej Brązert ${ }^{2}$ - Joanna Budna ${ }^{3}$ - Piotr Celichowski ${ }^{3}$ - Artur Bryja ${ }^{1}$ - Mariusz J. Nawrocki ${ }^{1}$. Katarzyna Ożegowska ${ }^{2} \cdot$ Maurycy Jankowski ${ }^{1}$ - Błażej Chermuła ${ }^{2} \cdot$ Marta Dyszkiewicz-Konwińska ${ }^{1,4} \cdot$ Michal Jeseta $^{5}$. Leszek Pawelczyk ${ }^{2} \cdot$ Andrzej Bręborowicz $^{6} \cdot$ Dominik Rachon $^{7} \cdot$ Małgorzata Bruska $^{1} \cdot$ Michał Nowicki $^{3}$. Maciej Zabel ${ }^{8,9} \cdot$ Bartosz Kempisty $^{1,3,5}$}

1 Department of Anatomy, Poznan University of Medical Sciences, 6 Święcickiego St, 60-781 Poznań, Poland
2 Division of Infertility and Reproductive Endocrinology, Department of Gynecology, Obstetrics and Gynecological 
Oncology, Poznan University of Medical Sciences, 33 Polna St, 60-535 Poznań, Poland

3 Department of Histology and Embryology, Poznan University of Medical Sciences, 6 Święcickiego St, 60-781 Poznań, Poland

4 Department of Biomaterials and Experimental Dentistry, Poznan University of Medical Sciences, 70 Bukowska St, 60-812 Poznań, Poland

5 Department of Obstetrics and Gynecology, University Hospital and Masaryk University, Jihlavská 20, 62500 Brno, Czech Republic
6 Department of Pathophysiology, Poznań University of Medical Sciences, 8 Rokietnicka St, 60-806 Poznan, Poland

7 Department of Clinical and Experimental Endocrinology, Medical University of Gdańsk, 7 Dębinki St, 80-211 Gdańsk, Poland

8 Division of Histology and Embryology, Department of Human Morphology and Embryology, Wroclaw Medical University, Wroclaw, Poland

9 Division of Anatomy and Histology, University of Zielona Góra, Zielona Góra, Poland 